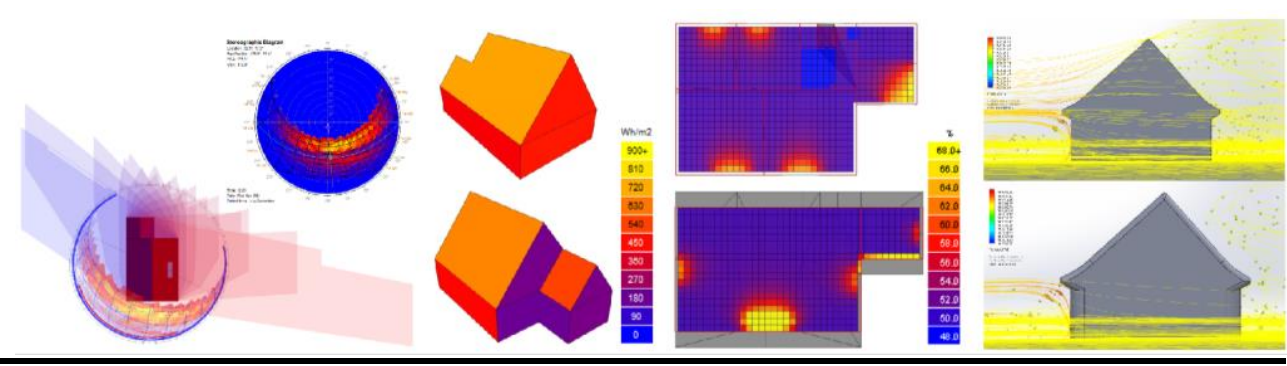

DOI: 10.21005/pif.2020.44.B-03

\title{
APPLICATION OF LCA AND BIM METHODS IN THE ARCHITECTURE OF A SINGLE-FAMILY HOUSE IN THE CHANGING CLIMATE OF WESTERN POMERANIA
}

\section{ZASTOSOWANIE METOD LCA ORAZ BIM W ARCHITEKTURZE DOMU JEDNORODZINNEGO W ZMIENIAJACYM SIĘ KLIMACIE POMORZA ZACHODNIEGO}

\author{
Piotr Gradziński \\ M.Sc. Eng. Arch. \\ Author's Orcid number: 0000-0002-5713-2309
}

West Pomeranian University of Technology in Szczecin

Faculty of Architecture

Departmenr of Housing and Technical-Ecological Foundations of Architecture

\begin{abstract}
The paper deals concerns the problem of energy optimization of single-family housing in Poland in Western Pomerania. The problem is considered because of the changing climate in the region and the consequences. This results in the search for changes in the architectural paradigm of singlefamily houses design and the use of appropriate technical solutions that minimize the environmental impact of these buildings. The problem of changes is considered in the category of building materials selection and the architectural form shape. In the analytical part, the following analyzes were carried out: in terms of the structures of the building in minimizing $\mathrm{CO}_{2}$ emissions and energy consumption of the building materials used and environmental factors (light, shade, wind) influencing energy consumption through the building's shape in the region.
\end{abstract}

Key words: LCA, BIM, sustainable development, architecture.

\section{STRESZCZENIE}

Artykuł dotyczy problemu optymalizacji energetycznej budownictwa jednorodzinnego w Polsce na Pomorzu Zachodnim. Problem jest rozważany ze względu na zmieniający się klimat w regionie i jego konsekwencje. Skutkuje to poszukiwaniem zmian w paradygmacie architektonicznym projektowania domów jednorodzinnych oraz zastosowaniem odpowiednich rozwiązań technicznych minimalizujących oddziaływanie budynków na środowisko naturalne. Problem zmian rozpatrywany jest w kategorii doboru materiałów budowlanych oraz kształtowania formy architektonicznej. W części analitycznej przeprowadzono analizy: struktury budynku w znaczeniu minimalizacji emisji $\mathrm{CO}_{2}$ i energochłonności zastosowanych materiałów budowlanych oraz czynników środowiskowych (świa-tła, cienia, wiatru) wpływających na konsumpcję energetyczną poprzez kształt budynków występu-jących w regionie.

Słowa kluczowe: LCA, BIM, zrównoważony rozwój, architektura. 


\section{INTRODUCTION}

The objective of this paper is to present a pursuit of changes in the architectural paradigm of single-family house design and the application of proper technical solutions that minimise the impact of buildings on the natural environment. The problem of the energy optimisation of construction and architecture is essential due to climate change and its later consequences in architectural design.

The first section familiarises readers with the climate of Western Pomerania, including current and probable changes to the region that are considered irreversible, such as stronger winds and the formation of flood plains. Afterwards, the paper features a characterisation of the area's singlefamily residential development.

The second part of the paper presents the concepts of Life Cycle Assessment (LCA) and Building Information Modelling (BIM). The analytical section of the LCA method was limited by a required service life (RSL) of 100 years. The calculations are based on an original calculator. They were performed based on data taken from environmental product declarations (EPDs). The results come in the form of global warming potential (GWP) and primary energy consumption (PE) of the construction materials used throughout the building's structure. In addition, a proper selection of construction material that would minimise negative environmental impact is indicated. The analyses were performed using $\mathrm{kgCO} 2 \mathrm{eq}$ and $\mathrm{MJ}$ units.

The analytical section dedicated to BIM points to the calculation-based justification of currently designed architectural forms of buildings encountered in the area under study. The study presents the shaping of the architectural form with the use of effective environmental and climatic factors. It leads to the optimisation of the building's shape. The study was performed in the context of analysing: shadow cast by the building; the annual insolation of the building's surface; annual indoor daylighting; wind load exerted on the single-family house (with an air velocity of $25 \mathrm{~m} / 2-90 \mathrm{~km} / \mathrm{h}$ ), and yearly passive solar energy gains and losses.

The findings of the study characterise changes in the structure and architecture of single-family houses. They lend credibility to the new approach to shaping architectural form and the selection of construction materials applied in single-family houses in the region under study with a focus on the sustainable development of architecture and the construction sector in an era of Anthropocenic climate change.

\section{OVERVIEW OF WESTERN POMERANIA}

West Western Pomerania is a region with a rich history and a wealth of natural assets. History has been defining its borders for centuries. The interests of Poland, Brandenburg, the State of the Teutonic Order, Mecklenburg, Sweden, Denmark and the German Empire all intersected here. At present, the borders of historical Western Pomerania are outlined by, among others, the West Pomeranian Voiovedship and a part of the Pomeranian Voivodeship together with the north-eastern part of the Vorpommern region of Germany.

The signing of an agreement on 15 December 1995 initiated the establishment of the Pomerania Euroregion, whose goal was defined as engaging in joint efforts towards even and sustainable development of the region and bringing residents on both sides of the border closer together.

\subsection{Overview of Western Pomerania's natural environment}

Western Pomerania has varied ecological and weather characteristics. This fact is important due to the character of the proper design of architecture that is adapted to a given region, its climate and ecosystem while accounting for, among other things, the weather. It is necessary to determine environmental factors, such as: placement, exposure to the sun and shading, or the wind load affecting the building, which determine the characteristics and later qualities of an eco-friendly architectural form. 
The West Pomeranian Voivodeship Environmental Protection Programme for the years 20162020, with a perspective towards 2024 (Program ochrony środowiska, 2016) includes a provision that the climate of the West Pomeranian Voivodeship is highly diverse. The coastal strip features a moderate, warm climate, while further inland it is moderate, warm and transitional. The climate diversity is based on the clashing of the marine and inland climate, as well as local factors, within its territory. This is why 10 climate zones have been distinguished in the region. Inland and westwards, the local climate changes, displaying higher summer temperatures and lower winter temperatures, as well as considerable temperature amplitudes throughout the day. Sudden temperature changes are the primary reason for the occurrence of extreme weather phenomena.

Due to its varied climatic and physiographic conditions, the territory of the West Pomeranian Voivodeship has been divided into 10 climate zones (Koźmiński, Michalska, Czarnecka, 2007).

The overview of the territory gives this study a physical dimension. The region's distinctive characteristics are essential to analyses in formulating conceptual design proposals for single-family houses. Frequent storms and hurricane-force winds are an important element that needs to be accounted for in the design of the future building (POGODA, 2020). It is worth mentioning that in 2019 , the following wind speeds were recorded in the area: Szczecin $91 \mathrm{~km} / \mathrm{h}$, Koszalin $91,8 \mathrm{~km} / \mathrm{h}$, Kołobrzeg $112 \mathrm{~km} / \mathrm{h}$. Wind is among essential climatic factors that determine changes in the approach to building design that account for eco-friendly properties for architectural form. It should be assumed that the values presented shall either remain at the reported level or increase. Wind speed data can be obtained from, among other places, www.irena.masdar.ac.ae.

It should be noted that climate change is perceivable all around the world, and the consequences of this state of affairs will affect the shape of the area under analysis. For presentation purposes, maps of areas in danger of flooding have been presented in figure 1 (fig. 1).

Fig. 1. Forecasts of sea level rise: A: area near Szczecin and Lake Dąbie; B: seaside area in the vicinity of Koszalin. Source: climatecentral.org (01.04.2020)

Ryc. 1. Przykład prognoz dotyczących wzrostu poziomu morza: A: obszar w rejonie Szczecina i jeziora Dąbie; B: obszar nadmorski w rejonie Koszalina. Źródło: climatecentral.org (dostęp: 01.04.2020)
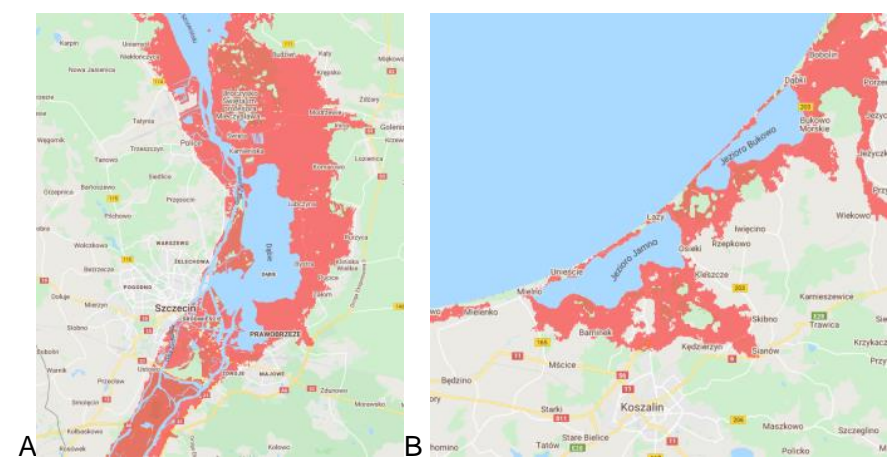

It It should be highlighted that fears associated with climate change within Polish cities were included in climate change adaptation plan drafts. The main threats to the city of Szczecin identified in relation to climate change are: medium risk of an rise in sea level and a high risk of strong and very strong winds and storms (including hailstorms), as well as heat waves (BIP, 2018, p. 31).

Another aspect of design that should be paid a greater deal of attention is the presence of a rich wildlife zone in the West Pomeranian Voivodeship. This area requires characterisation concerning the presence of, among others: surface waters, national parks, landscape parks, nature preserves and individually present landscape and wildlife areas (Kępka, Kępka, Kępka, 2013).

Characterising the natural environment is important due to conducting a design process that accounts for the balance of the climatic and environmental factors present. The negative impact of construction on the natural environment results in climate change. Thus, climate change affects the shape and functioning of architecture. It is possible to subject architecture to numerous analyses: the identification, analysis and determination of an optimal solution based on multiple repetitions 
and calculations of inputs and outputs already during the initial phase of the design process, on a computer screen (tab. 1).

Tab.1. Benefits of conducting analyzes with digital analytical tools. Source: author

\begin{tabular}{|c|c|c|}
\hline \multicolumn{3}{|c|}{ Benefits of conducting analyzes with digital analytical tools } \\
\hline $\begin{array}{l}\text { Element of the envi- } \\
\text { ronment, a compo- } \\
\text { nent of the built envi- } \\
\text { ronment }\end{array}$ & Factor & $\begin{array}{l}\text { The conclusions from the analyzes allow for the conscious shaping of urban } \\
\text { tissue and buildings under the influence of exogenous factors. } \\
\text { Design solutions reach their full size in terms of human health due to climate } \\
\text { change through the analysis of input and output parameters. }\end{array}$ \\
\hline Light & $\begin{array}{l}\text { drought } \\
\text { excess } \\
\text { shadow }\end{array}$ & $\begin{array}{l}\text { Correct formation of passive objects and objects using renewable energy sources. } \\
\text { Finding and maintaining optimal distances between objects, enabling the minimiza- } \\
\text { tion of shade and the penetration of natural light. } \\
\text { Protection against excess light. }\end{array}$ \\
\hline Wind & $\begin{array}{c}\text { lack } \\
\text { hurricanes }\end{array}$ & $\begin{array}{l}\text { Finding suitable locations for facilities that use renewable energy sources. } \\
\text { Minimizing or developing wind corridors. }\end{array}$ \\
\hline Water & $\begin{array}{l}\text { floods } \\
\text { drought }\end{array}$ & Forming buildings that can collect rainwater. \\
\hline Sound & excess & $\begin{array}{l}\text { Forming buildings and surrounding spaces to reduce the negative impact on hu- } \\
\text { man perception (soundscape). }\end{array}$ \\
\hline
\end{tabular}

The proper analysis and qualification of results enables the calculation of data that confer the correct optimal parametric result to architectural and urban forms. Conducting a design process that integrates and implements analyses (using LCA and BIM) for future (urban) areas in terms of light, sound and wind provides a basis for later design decisions made on the urban and architectural scale and that affect the condition of the built and natural environments to be correct.

\subsection{Overview of the built environment in the territory of Western Pomerania}

The Pomerania Euroregion occupies an area of around 41 thousand $\mathrm{km} 2$ and is inhabited by over 3.4 million people. The Polish section consists of the Polish Municipalities of the Pomerania Euroregion Association, whose members include most municipalities of the West Pomeranian Voivodeship. Major cities with populations in excess of 50 thousand (as reported in December 2015) in the Pomerania Euroregion include Szczecin 405,657, Koszalin 107,970, Słupsk 92,496, Stargard 68,670 .

This data is important in terms of matter consumed: materials and energy required for the proper functioning of buildings and the housing environment. An enclosed form of the house enables analyses that determine impacts in the context of emissions, including: greenhouse gasses (e.g. GWP), energy consumption ( $\mathrm{kWh}$ ), but also the potential to absorb pollution (CO2 sequestration), bioretention and resource accumulation, as well as renewable energy surplus (energy + ).

It should be noted that in the years 2009-2019, built-up and urbanised areas increased from 96,156 ha to 102,575 ha in the West Pomeranian Voivodeship, similarly to housing areas, which grew from 10,697 ha to 13,111 ha.

Single-family buildings erected in Western Pomerania are, from the standpoint of the materials provided by the General Statistics Office, impossible to characterise on the basis of their construction technology and thus the amounts of construction materials used. However, site visits and information from the General Statistics Office website (GUS), lend credibility to the statement that they are mostly buildings erected using improved traditional technology. The main elements of such buildings can be described as typical, and which usually include the following structural solutions: foundations: strip footing and slab on grade or a slab foundation, load-bearing walls: aerated concrete or ceramic masonry units, lintels: prestressed or reinforced concrete, decks: slabs with 
prefabricated lattices or monolithic reinforced concrete slabs, high-pitched roofs: with a timber structure.

Analyses of selected housing estates composed of detached single-family houses and located in the territory of the West Pomeranian Voivodeship were performed. No pursuits of a form that would follow the environment were noted. Elements that (in a sense) defined the form and aesthetics of the buildings were considerations arising from the provisions of local spatial development plans or planning permits. The development under analysis was found to be characterised by the use of typical structural and material solutions encountered in Poland. Construction materials in the structure of these buildings are in widespread use. These include the following design solutions: external walls made from aerated concrete and covered with expanded polystyrene, a traditional foundation structure, a roof and PVC windows. The material solutions do not bear signs of being ecofriendly in character.

The most common form of single-family house in Western Pomerania has a massing that is similar in shape to a cube, with a high-pitched gable, hipped or multi-slope roof. The plot area ranges between 800 and 1,200 m2, while the built-up-area-to-plot ratio ranges between 30 and $40 \%$. However, tendencies in the design of architectural form of single-family houses are also the product of their developers' and owners' creativity, both in Western Pomerania and elsewhere. The Spatial Planning and Development Act of 27 March 2003 features a definition of the term 'spatial order'. Following the meaning of this term, it can be presumed that newly-designed and newly-built buildings shall form a harmonious whole, for instance in compositional and aesthetic terms. However, the insufficient number of local spatial development plans (in Szczecin they were found to cover $59.46 \%$ of the city's territory as of the time of writing this paper) (BIP, 2020) and the flexibility of planning permits grant observable and hurtful freedom to design architecture of low aesthetic value.

\section{LIFE CYCLE ANALYSIS AND BUILDING INFORMATION MODELLING AS APPLIED TO SINGLE-FAMILY HOUSES}

The The housing stock in the area under analysis is, as an existing material form (houses), characterised by a relative energy consumption and the materials included in it (substance and energy). The analysis presented herein focused on detached single-family houses in existing development. Accounting for the structure and functioning of the house, the analyses were aimed at answer the following question: what is the impact exerted by the building and the entire building complex under study on the ecosystem, pointing to $\mathrm{CO} 2$ emissions generated by the consumption of energy from non-renewable sources (natural gas, coal, oil)? It estimated that embodied energy, which is responsible for harmful emissions generated throughout the life cycle of construction products, ranging from resource acquisition, through manufacturing, transport and incorporation into the structure of a building. At present, science and engineering aim to lower the consumption of energy from non-renewable sources in the construction sector (necessary for its correct functioning). This is why it is important to minimise the share of embodied energy in the entire life cycle of materials within buildings, which should be deliberately decreased relative to a building's operational emissions. This enables the imaging of their impact on the ecosystem. One should assume the necessity of making sustainable design decisions aimed at minimising building impact on wildlife across its life cycle.

It should be noted that, at present, the construction of a house generates a specific amount of various types of negative impacts (CO2) and consumption: of energy, water and natural resources. The design and construction of single-family houses should lead to the pursuit of solutions in the sphere of energy-efficient, low-energy and eco-friendly buildings. Such buildings are classified as: smart buildings, low-emission buildings (CO2), passive buildings, zero- or plus-energy buildings, which are characterised by a holistic approach to the design, occupancy and life cycle of the building (Przesmycka, 2012, Czarnecki, Rytel, 2013). The last of these elements, which is of interest to this study, should make its way into legislation (at present, only Life Cycle Costing - LCC - has been introduced, which only applies to the Public Procurement Law Act) concerning the design of 
single-family houses, so that individual housing construction can meet the requirements featured in the notion of sustainable development in the future. The analyses of development performed indicate that to determine the impact of single-family development on the natural environment, it is essential to identify the energy consumption across a building's life cycle and thus the full extent of its impact on the environment. The author agrees with the conclusions drawn by Sarosiek and Sadowska (Sarosiek, Zadowska, 2009), who indicated that the minimisation of energy should apply to all visible stages. However, if we assume the total amount of energy consumed across the entire life cycle to be $100 \%$, then the manufacturing of materials and the construction of the building amounts to $10-12 \%$, renovations and dismantlement amount to around 5\%, while occupancy amounts to as much as $83-85 \%$ of this energy. These authors characterised the change in estimated values of the heating energy demand indicator over time.

It should be highlighted that major design decisions are made and implemented during the conceptual design phase and have a direct impact on the energy performance of the building. In the conceptual phase, designers require simple methods and quick answers concerning the comparative assessment of the ideas and architectural concepts they propose. Among others, a building's thermal energy demand is a result of both technical and architectural choices made during the initial stage of design. Design solutions that affect thermal energy demand (which affect heat gain and loss within a building) also include design decisions that affect the architectural design itself, such as: the site, the building's orientation relative to the cardinal directions, the placement and surface area of doors and windows; the material applied in the building's 'skin and bones'.

\subsection{Analysis of the elements and structure of single-family houses in Western Pomerania with the application of LCA and BIM}

A detached single-family house was subjected to Life Cycle Assessment and an analysis to probe the impact of the construction materials featured in its structure on the natural environment. The study was based on preparing a calculation sheet in Microsoft Excel ${ }^{1}$ and entering data from the Environment Product Declaration (EPD). EPDs include the estimated service life of the product, so the results show the sum required for possible renovations, i.e. the replacement of materials due to the expiry of their Reference Service Life (RSL). As a result, the author calculated the impact of the building's construction material on the building across its full assumed life cycle (100 years). This enabled the estimation of the environmental impact of the building's construction materials across its entire structure, accounting for essential information and parameters and assuming a fixed duration of its operation; which includes: Global Warming Potential (GWP); Total use of non-renewable primary energy resources (PENRT); Total use of renewable primary energy resources (PERT); Use of net fresh water (FW); Non-hazardous waste disposed (NHWD); Hazardous waste disposed (HWD); Radioactive waste disposed (RWD), Components for re-use (CRU); Materials for recycling (MFR); Materials for energy recovery (MER). However, a probable calculation error must be assumed due to the conceptual/simplified character of the analysis.

During the first stage, the analysis covered an area including development with single-family houses that were repetitive because the community was gated. Benefits concerning energy and derived from the architectural form were analysed in this area.

During the second stage, the value of the $U$ heat transfer coefficient was determined for partitions within the building, with two intervals: the first was determined for the period of construction, namely 1933, while the second met current requirements as stipulated in standards and the Ordinance on the technical conditions to be met by buildings and their placement. The analysis was also extended to determine the impact of light timber structure on the environment. The analysis of the building's form, along with the U-value, aided in determining the benefits from the building's form so that it could (but would not have to) receive the maximum passive solar energy gains.

\footnotetext{
${ }^{1}$ The author prepared an original calculator so as to ensure reliable calculations, as free LCA software allows calculations that utilise estimated or unified values. Thus, to obtain actual values for each product, the author used specific environmental product declarations (EPDs) found online. Source: http://www.environdec.com, http://www.knaufinsulation.com/, http://www.epd-online.com, http://www.ibu-epd.com/ (accessed on: 01.11.2017)
} 
In the third stage-a reference building was subjected to a Life Cycle Assessment of its construction materials in terms of their impact on the natural environment, accounting for LCA elements: Before Use, during Use, and at the End of Life, in addition to the Benefits and loads beyond the system boundaries. In the last stage, the percentage share of the construction materials in the building's structure was indicated in terms of energy consumption (PENRT+PERT) and their global warming potential (GWP).

Afterwards, the same buildings were subjected to an analysis using specialist software with BIM tools. The study, which used digital analytical tools, investigated detached single-family houses. The following analyses were performed first: an analysis of shade cast by the building on 21 March and 21 September between 10 AM and 2 PM, the annual insolation of the building's surface and the annual daylighting of the building's indoor spaces. Studies using computer software determine the amount of conventional energy necessary for the building's functioning and the possibility of passively obtaining energy - the building's energy gains and losses, determining four parameters: Sol-Air-gains from direct sunlight that falls onto exposed construction materials; Solar-direct heat gains from solar radiation that enters the interior; gains due to the use of translucent surfaces (windows and roof windows), while Sol-Air refers gains and losses through opaque surface; Ventilation-includes gains and losses from ventilation and infiltration; Internal-denotes gains from artificial lighting, the presence of people and electrical equipment.

Below is a presentation of the results obtained via LCA and BIM.

\subsubsection{Analysis using the LCA method}

The building from 1933, as the base example, was analysed first (tab. 2, fig. 2). During the second stage, the same building was analysed, in a version that conformed to the parameters stipulated in the Ordinance on the technical conditions to be met by buildings and their placement (tab. 3, fig. 3). The author also analysed a building erected in timber-frame technology that conformed to the Ordinance's requirements (tab. 4, fig. 4). This showcases the changes that the base building has undergone while accounting for the different construction materials. Currently built houses erected as a part of single-family developments in Western Pomerania were analysed using the same formula: Szeroka Estate, Szczecin (tab. 5, fig. 5), Laurowe Estate, Koszalin (tab. 6, fig. 6), Tęczowe Estate, Stargard (tab. 7, fig. 7).

Tab. 2. The sum (according to the calculations of the Life Cycle Analysis made with the use of EPD and the prepared calculator in Microsoft Excel) of building materials used in the building structure from 1933 in the assumed time period of 100 years. Source: author.

\begin{tabular}{|c|c|c|c|c|c|c|c|c|c|}
\hline \multicolumn{10}{|c|}{ IMPACT OF BUILDING MATERIALS } \\
\hline $\begin{array}{c}\text { GWP } \\
\mathrm{kgCO}_{2} \text {-eQ. }\end{array}$ & $\begin{array}{c}\text { PENRT } \\
\mathrm{MJ}\end{array}$ & $\begin{array}{c}\text { PERT } \\
\mathrm{MJ}\end{array}$ & $\begin{array}{c}\text { FW } \\
\mathrm{m}^{3}\end{array}$ & $\begin{array}{c}\text { NHWD } \\
\mathrm{kg}\end{array}$ & $\begin{array}{c}\text { HWD } \\
\mathrm{kg}\end{array}$ & $\begin{array}{c}\text { RWD } \\
\mathrm{kg}\end{array}$ & $\begin{array}{c}\text { CRU } \\
\mathrm{kg}\end{array}$ & $\begin{array}{c}\text { MFR } \\
\mathrm{kg}\end{array}$ & $\begin{array}{c}\text { MER } \\
\text { MJ }\end{array}$ \\
\hline 41885,6 & 605009,7 & 86731,7 & 12940,7 & 23096,7 & 2357,2 & 0,3 & 22860 & 31513,0 & 381,8 \\
\hline
\end{tabular}

Fig. 2. Percentage share of the materials used in the building structure: $A$ : PENRT+PERT, B: GWP. Source: author Ryc. 2. Procentowy udziału zastosowanych materiałów budowlanych $w$ strukturze budynku: A: PENRT+PERT, B: GWP. Źródło: autor
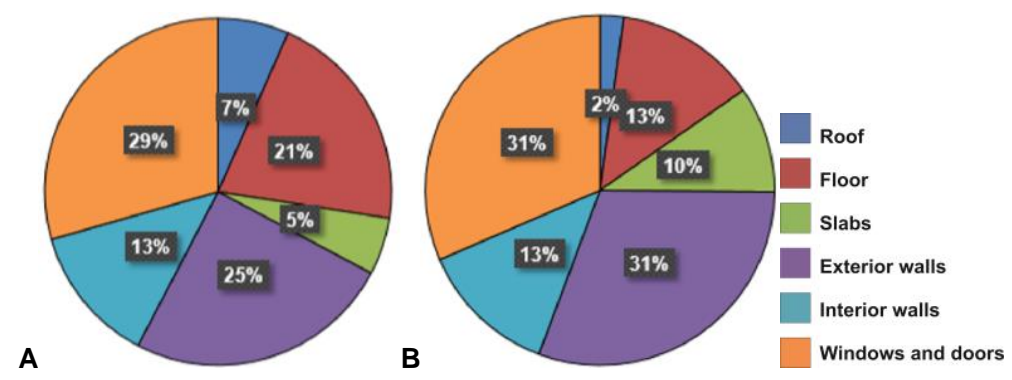
Tab. 3. The sum (according to the calculations of the Life Cycle Analysis made with the use of EPD and the prepared calculator in Microsoft Excel) of building materials used in the building structure according to WT 2017 in the assumed time period of 100 years. Source: author.

\begin{tabular}{|c|c|c|c|c|c|c|c|c|c|}
\hline \multicolumn{10}{|c|}{ IMPACT OF BUILDING MATERIALS $\left(57,6 \mathrm{kWh} / \mathrm{m}^{2} / \mathrm{y}\right)$ ON THE ENVIRONMENT IN THE FULL LIFE CYCLE (100y) } \\
\hline $\begin{array}{c}\text { GWP } \\
\mathrm{kgCO}_{2}-\mathrm{eQ} .\end{array}$ & $\begin{array}{c}\text { PENRT } \\
\text { MJ }\end{array}$ & $\begin{array}{l}\text { PERT } \\
\text { MJ }\end{array}$ & $\begin{array}{l}\mathrm{FW} \\
\mathrm{m}^{3}\end{array}$ & $\begin{array}{c}\text { NHWD } \\
\mathrm{kg}\end{array}$ & $\begin{array}{c}\text { HWD } \\
\mathrm{kg}\end{array}$ & $\begin{array}{c}\text { RWD } \\
\text { kg }\end{array}$ & $\begin{array}{c}\text { CRU } \\
\mathrm{kg}\end{array}$ & $\begin{array}{c}\text { MFR } \\
\mathrm{kg}\end{array}$ & $\begin{array}{c}\text { MER } \\
\text { MJ }\end{array}$ \\
\hline 77679,3 & 728790,0 & 53588,1 & 17716,3 & 34535,2 & 2265,9 & 3,0 & 55,2 & 2956,3 & 448,5 \\
\hline & \multicolumn{2}{|c|}{ PENRT+PERT - MJ } & & & & & & & \\
\hline & \multicolumn{2}{|c|}{782378,1} & & & & & & & \\
\hline
\end{tabular}
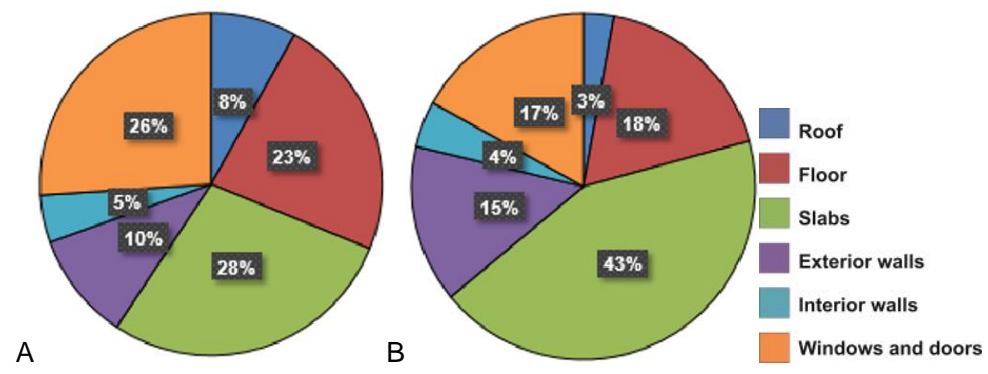

Fig. 3. Percentage share of the materials used in the building structure: $A$ : PENRT+PERT, B: GWP. Source: author

Ryc. 3. Procentowy udziału zastosowanych materiałów budowlanych $w$ strukturze budynku: A: PENRT+PERT, B: GWP. Źródło: autor

Tab. 4. The sum (according to the calculations of the Life Cycle Analysis made with the use of EPD and the prepared calculator in Microsoft Excel) of the building materials used in the building structure in wooden structure in the assumed time period of 100 years. Source: author.

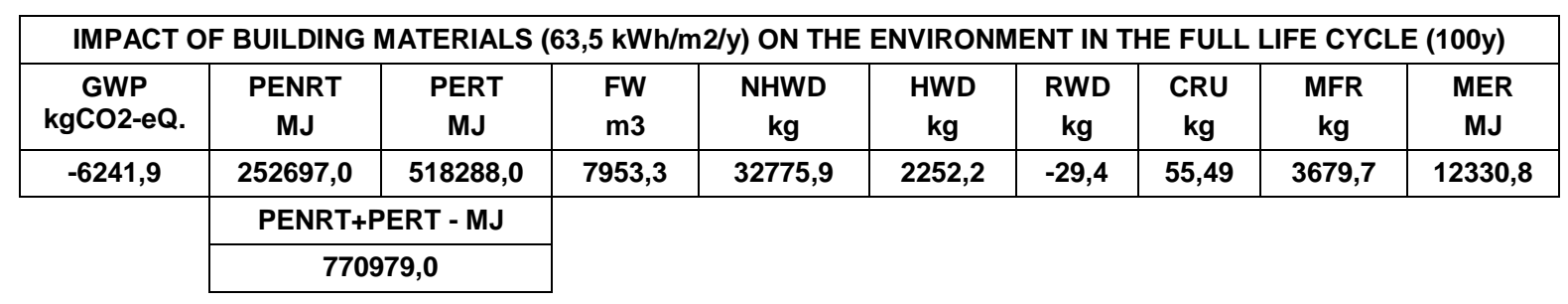

A

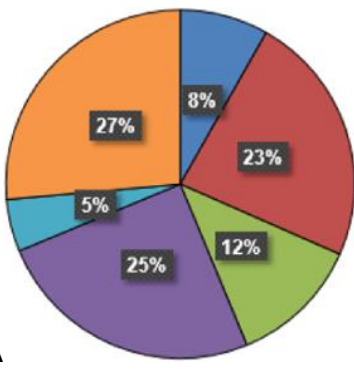

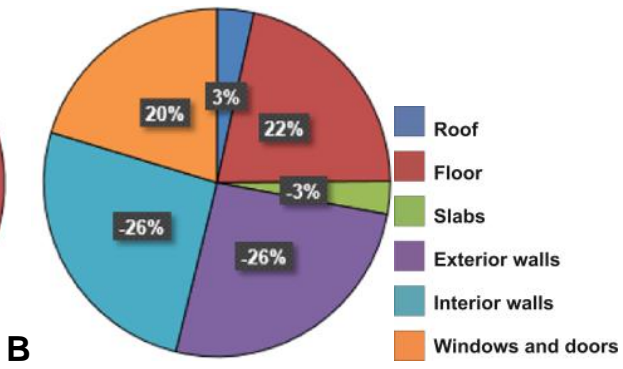

Fig. 4. Percentage share of the materials used in the building structure: A: PENRT+PERT, B: GWP. Source: author

Ryc. 4. Procentowy udziału zastosowanych materiałów budowlanych $\mathrm{w}$ strukturze budynku: A:

PENRT+PERT, B: GWP. Źródło: autor

Tab. 5. The sum (according to the calculations of the Life Cycle Analysis made with the use of EPD and the prepared calculator in Microsoft Excel) of building materials used in the building structure in the assumed time period of 100 years for a single-family house located in the Szeroka estate in Szczecin - Building No. 1. Source: author.

\begin{tabular}{|c|c|c|c|c|c|c|c|c|c|}
\hline \multicolumn{10}{|c|}{ IMPACT OF BUILDING MATERIALS (49,1 kWh/m2/y) ON THE ENVIRONMENT IN THE FULL LIFE CYCLE (100y) } \\
\hline $\begin{array}{c}\text { GWP } \\
\mathrm{kgCO2-eQ} .\end{array}$ & $\begin{array}{l}\text { PENRT } \\
\text { MJ }\end{array}$ & $\begin{array}{l}\text { PERT } \\
\text { MJ }\end{array}$ & $\begin{array}{l}\mathrm{FW} \\
\mathrm{m} 3\end{array}$ & $\begin{array}{c}\text { NHWD } \\
\text { kg }\end{array}$ & $\begin{array}{c}\text { HWD } \\
\text { kg }\end{array}$ & $\begin{array}{c}\text { RWD } \\
\text { kg }\end{array}$ & $\begin{array}{c}\text { CRU } \\
\text { kg }\end{array}$ & $\begin{array}{c}\text { MFR } \\
\mathrm{kg}\end{array}$ & $\begin{array}{c}\text { MER } \\
\text { MJ }\end{array}$ \\
\hline 78682,8 & 1556736,5 & 471816,6 & 114665,0 & 27512,6 & 851,4 & 2,3 & 29,3 & 71559,3 & 0 \\
\hline & \multicolumn{2}{|c|}{ PENRT+PERT - MJ } & & & & & & & \\
\hline & \multicolumn{2}{|c|}{2028553,1} & & & & & & & \\
\hline
\end{tabular}



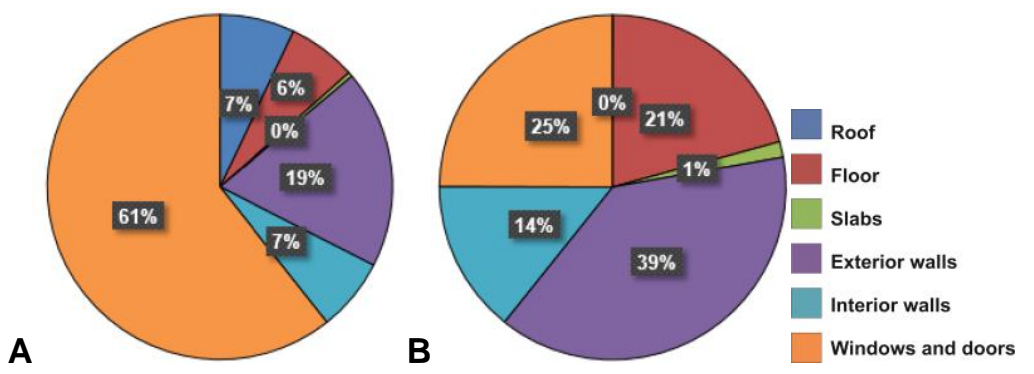

Fig. 5. Percentage share of the materials used in the building structure: A: PENRT+PERT, B: GWP.

Source: author

Ryc. 5. Procentowy udziału zastosowanych materiałów budowlanych w strukturze budynku nr 1: A: PENRT+PERT, B: GWP. Źródło: autor

Tab. 6. The sum (according to the calculations of the Life Cycle Analysis made with the use of EPD and the prepared calculator in Microsoft Excel) of building materials used in the building structure in the assumed time period of 100 years for a single-family house located in Osiedle Laurowe in Koszalin - Building No. 2. Source: author.

\begin{tabular}{|c|c|c|c|c|c|c|c|c|c|}
\hline \multicolumn{10}{|c|}{ IMPACT OF BUILDING MATERIALS (88,2 kWh/m2/y) ON THE ENVIRONMENT IN THE FULL LIFE CYCLE (100y) } \\
\hline $\begin{array}{c}\text { GWP } \\
\text { kgCO2-eQ. }\end{array}$ & $\begin{array}{c}\text { PENRT } \\
\text { MJ }\end{array}$ & $\begin{array}{c}\text { PERT } \\
\text { MJ }\end{array}$ & $\begin{array}{l}\text { FW } \\
\text { m3 }\end{array}$ & $\begin{array}{c}\text { NHWD } \\
\text { kg }\end{array}$ & $\begin{array}{c}\text { HWD } \\
\text { kg }\end{array}$ & $\begin{array}{c}\text { RWD } \\
\text { kg }\end{array}$ & $\begin{array}{c}\text { CRU } \\
\text { kg }\end{array}$ & $\begin{array}{c}\text { MFR } \\
\text { kg }\end{array}$ & $\begin{array}{c}\text { MER } \\
\text { MJ }\end{array}$ \\
\hline 41804,8 & 1327693,2 & 528587,2 & 136349,2 & 82314,7 & 7,8 & 8,5 & 11,0 & 108090,8 & 0 \\
\hline \multicolumn{3}{|c|}{ PENRT+PERT - MJ } & & & & & & & \\
\hline & \multicolumn{2}{|c|}{691741,5} & & & & & & & \\
\hline
\end{tabular}

A

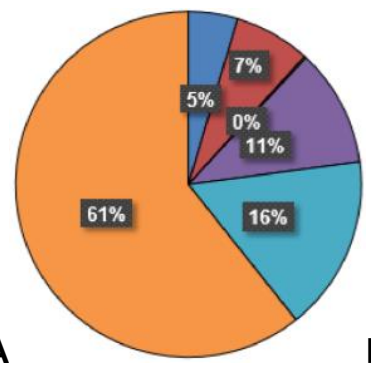

B

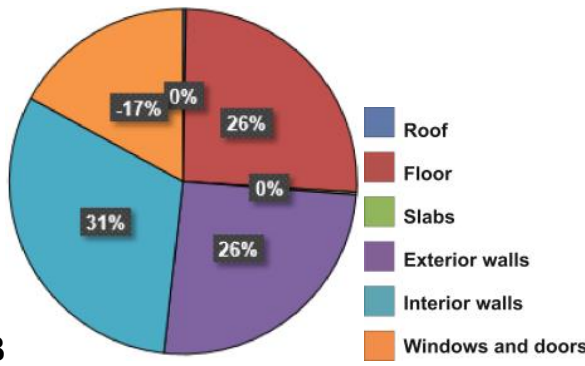

Fig. 6. Percentage share of the materials used in the building structure: $A$ : PENRT+PERT, B: GWP. Source: author

Ryc. 6. Procentowy udziału zastosowanych materiałów budowlanych w strukturze budynku nr 2: A:

PENRT+PERT, B: GWP. Źródło: autor

Tab. 7. The sum (according to the calculations of the Life Cycle Analysis made with the use of EPD and the prepared calculator in Microsoft Excel) of building materials used in the building structure in the assumed time period of 100 years for a single-family house located in the Tęczowe Estate in Stargard - Building No. 3. Source: author.

\begin{tabular}{|c|c|c|c|c|c|c|c|c|c|}
\hline \multicolumn{10}{|c|}{ IMPACT OF BUILDING MATERIALS (67,6 kWh/m2/y) ON THE ENVIRONMENT IN THE FULL LIFE CYCLE (100y) } \\
\hline $\begin{array}{c}\text { GWP } \\
\text { kgCO2-eQ. }\end{array}$ & $\begin{array}{c}\text { PENRT } \\
\text { MJ }\end{array}$ & $\begin{array}{l}\text { PERT } \\
\text { MJ }\end{array}$ & $\begin{array}{l}\text { FW } \\
\text { m3 }\end{array}$ & $\begin{array}{c}\text { NHWD } \\
\text { kg }\end{array}$ & $\begin{array}{c}\text { HWD } \\
\text { kg }\end{array}$ & $\begin{array}{c}\text { RWD } \\
\text { kg }\end{array}$ & $\begin{array}{c}\text { CRU } \\
\text { kg }\end{array}$ & $\begin{array}{c}\text { MFR } \\
\text { kg }\end{array}$ & $\begin{array}{c}\text { MER } \\
\text { MJ }\end{array}$ \\
\hline \multirow[t]{3}{*}{78682,8} & 1556736,5 & 471816,6 & 114665,0 & 27512,6 & 851,4 & 2,3 & 29,3 & 71559,3 & 0 \\
\hline & \multicolumn{2}{|c|}{ PENRT+PERT - MJ } & & & & & & & \\
\hline & \multicolumn{2}{|c|}{2028553,1} & & & & & & & \\
\hline
\end{tabular}

A

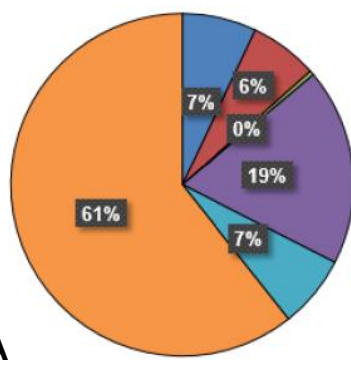

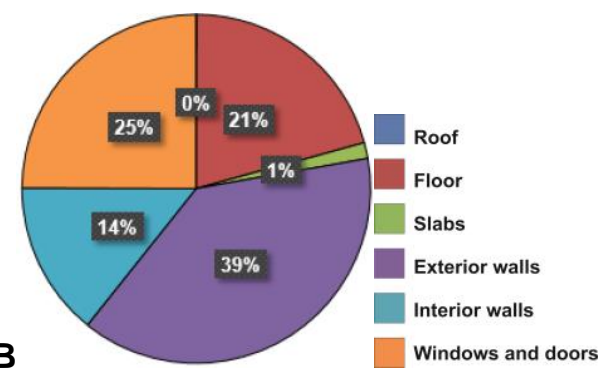

Fig. 7. Percentage share of the materials used in the building structure: A: PENRT+PERT, B: GWP. Source: author

Ryc. 7. Procentowy udziału zastosowanych materiałów budowlanych w strukturze budynku nr 3: A: PENRT+PERT, B: GWP. Źródło: autor 
The analyses showed how the building (in this case a free-standing single-family house) impacts the environment and how the analysis itself, performed using specialist software, enables determining its impact on the natural environment. This enables the detection of construction materials that impact the environment and aids their replacement. In this case, this applies to external walls (tab. 8).

Tab. 8. Changes in building materials in the structure of external walls according to the calculations of the Life Cycle Analysis. Source: author.

\begin{tabular}{|c|c|c|c|}
\hline & Building no 1 & Building no 2 & Building no 3 \\
\hline Before changes & $\begin{array}{c}\text { GWP } \\
30 \text { 350,50 kgCO2-Eq. } \\
\text { PENRT+PERT } \\
381 \text { 192,07 MJ }\end{array}$ & $\begin{array}{c}\text { GWP } \\
16 \text { 163,32 kgCO2-Eq. } \\
\text { PENRT+PERT } \\
203970,63 \mathrm{MJ}\end{array}$ & $\begin{array}{c}\text { GWP } \\
8 \text { 222,63 kgCO2-Eq. } \\
\text { PENRT+PERT } \\
103 \text { 323,83 MJ }\end{array}$ \\
\hline After changes & $\begin{array}{c}\text { GWP } \\
20 \text { 984,31 kgCO2-Eq. } \\
\text { PENRT+PERT } \\
271 \text { 278,02 MJ }\end{array}$ & $\begin{array}{c}\text { GWP } \\
8 \text { 708,56 kgCO2-Eq. } \\
\text { PENRT+PERT } \\
116604,28 \mathrm{MJ}\end{array}$ & $\begin{array}{c}\text { GWP } \\
4 \text { 584,43 kgCO2-Eq. } \\
\text { PENRT+PERT } \\
60669,40 \mathrm{MJ}\end{array}$ \\
\hline
\end{tabular}

The analyses enable a priori indication of: how to building the structure, what materials to use, how to design its form so that it can make the best use of natural conditions, i.e. the sun, wind, water, the shape of the terrain, etc. This model of work using software provides rational results, which, in aesthetic and ecological terms, are valuable due to the eco-friendly character of design solutions. It also leads to there being little need to introduce a posteriori changes to the buildings.

\subsubsection{Analysis using the BIM method}

Most problems associated with the building's functioning as a structure within the environment were analysed. The analyses included: an analysis of the shade cast by the building on 21 March and 21 September; an analysis of the insolation of the building's surfaces; an analysis of the annual daylighting of the building's indoor spaces. The analyses were performed using Autodesk Revit and Ecotect Analysis; Wind load analysis was performed using Solidworks: Flow Simulation; an analysis of annual passive solar energy gains and losses Loss (-\%) and gain (+\%) calculations for all thermal zones within the building: from 1 January to 31 December were made using Autodesk Ecotect Analysis.

The first building to be analysed was once again the base building from the beginning of the twentieth century. It should be noted that the author determined how the building cast its own shadow, the amount (intensity) of daylight entering the building throughout the year and the amount of solar energy from sunlight falling onto the building's service are elements that can be used in terms of active, passive or compilatory energy generation installation. Furthermore, in the wind load analysis, changes in shape were introduced to the digital model to account for the minimisation of wind impact on the building's structure (fig. 8).

An analysis of annual solar energy gains and losses was performed on the base building from 1933. Afterwards, for comparison, the same building was analysed as a version that complied with the requirements stipulated in the Ordinance for 2017; the building erected using timber-frame technology that complied with the Ordinance; and a building that met the requirements of a passive building (tab. 9). 


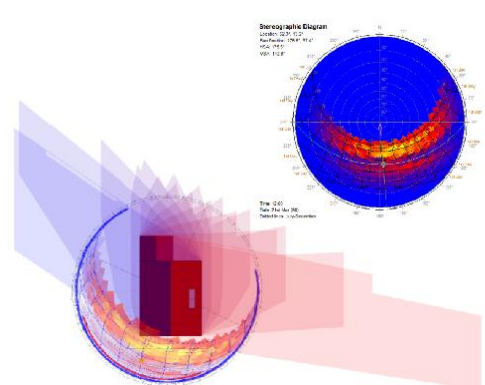

A

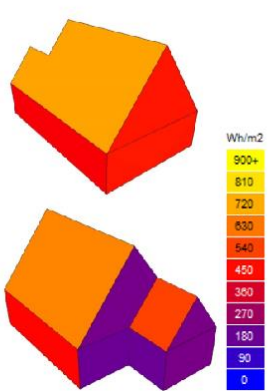

B

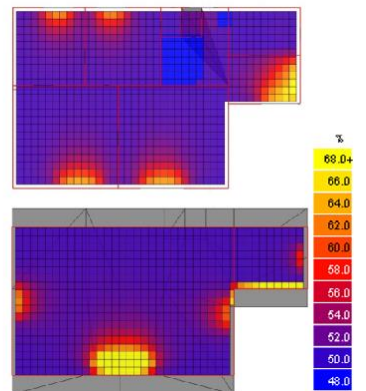

C

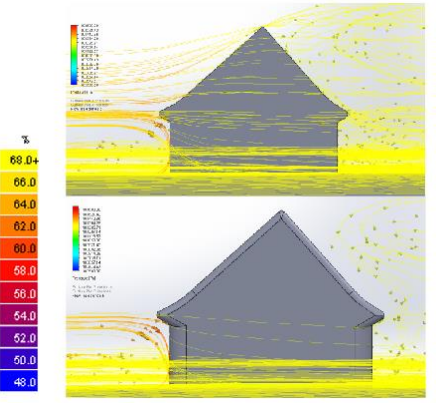

D

Fig. 8. A: Building shadow cast analysis on March 21 and September 21; B: Analysis of the annual insolation of the building surface; C: Analysis of the annual daylight access to the rooms in the building - the analyzes were performed using: Autodesk: Ecotect Analysis; D: Analysis of the wind load of a single-family house. Minimization of wind pressure on the building structure - the analyzes were performed using: Solidworks: Flow Simulation. Source: author

Ryc. 8. A: Analiza rzucania cienia przez budynek w dniach: 21 marca i 21 września; B: Analiza rocznego nasłonecznienia powierzchni budynku; C: Analiza rocznego dostępu światła dziennego do pomieszczeń w budynku - analiz dokonano przy użyciu: Autodesk: Ecotect Analysis; D: Analiza obciążenia wiatrem domu jednorodzinnego. Minimalizacja ciśnienia wiatrem na strukturę budynku - analiz dokonano przy użyciu: Solidworks: Flow Simulation. Żródło: autor

Tab. 9. Analysis of the annual energy gains and losses of the building from passive gains from solar radiation - the analyzes were made using: Autodesk: Ecotect Analysis. Source: author

\begin{tabular}{|c|c|c|c|}
\hline Base building from 1933 & $\begin{array}{l}\text { The building meets the } \\
\text { requirements of the Tech- } \\
\text { nical Conditions of } 2017\end{array}$ & $\begin{array}{l}\text { A building that meets the } \\
\text { requirements of the } 2017 \\
\text { Technical Conditions in a } \\
\text { wooden construction }\end{array}$ & $\begin{array}{l}\text { A building that meets the } \\
\text { requirements of a passive } \\
\text { house }\end{array}$ \\
\hline $\begin{array}{l}\text { Calculations of losses (-\%) } \\
\text { and profits (+\%) for all } \\
\text { thermal zones of the build- } \\
\text { ing: from January } 1 \text { to } \\
\text { December } 31: \\
\text { SOL-AIR }+55.8 \% \text {, } \\
\text { SOLAR }+11.6 \% \text {, } \\
\text { VENTILATION }-20.2 \% \text {, } \\
\text { INTERNAL }+28.7 \%\end{array}$ & $\begin{array}{l}\text { Calculations of losses (-\%) } \\
\text { and profits (+\%) for all } \\
\text { thermal zones of the build- } \\
\text { ing: from January } 1 \text { to } \\
\text { December } 31 \text { : } \\
\text { SOL-AIR }+9.5 \% \text {, } \\
\text { SOLAR }+22.4 \% \text {, } \\
\text { VENTILATION }-55.0 \% \text {, } \\
\text { INTERNAL }+67.3 \%\end{array}$ & $\begin{array}{l}\text { Calculations of losses (-\%) } \\
\text { and profits }(+\%) \text { for all ther- } \\
\text { mal zones of the building: } \\
\text { from January } 1 \text { to December } \\
31 \text { : } \\
\text { SOL-AIR }+8.1 \% \text {, } \\
\text { SOLAR }+22.8 \% \text {, } \\
\text { VENTILATION }-71.9 \% \text {, } \\
\text { INTERNAL }+68.4 \%\end{array}$ & $\begin{array}{l}\text { Calculations of losses (-\%) } \\
\text { and profits (+\%) for all } \\
\text { thermal zones of the build- } \\
\text { ing: from January } 1 \text { to } \\
\text { December } 31 \text { : } \\
\text { SOL-AIR }+5.1 \% \text {, } \\
\text { SOLAR }+45.1 \% \text {, } \\
\text { VENTILATION }-76.5 \% \text {, } \\
\text { INTERNAL }+47.2 \%\end{array}$ \\
\hline $\begin{array}{l}\text { Energy demand } 294,151 \\
\mathrm{kWh} / \mathrm{m}^{2} / \mathrm{rok} \text {. }\end{array}$ & $\begin{array}{l}\text { Energy demand } 57,674 \\
\mathrm{kWh} / \mathrm{m}^{2} / \mathrm{rok} \text {. }\end{array}$ & $\begin{array}{l}\text { Energy demand } 63,506 \\
\mathrm{kWh} / \mathrm{m}^{2} / \mathrm{rok} \text {. }\end{array}$ & $\begin{array}{l}\text { Energy demand } 34,5 \mathrm{k} \\
\mathrm{Wh} / \mathrm{m}^{2} / \mathrm{rok} \text {. }\end{array}$ \\
\hline
\end{tabular}

Following the same analysis formula, intended to maximise and minimise the parameters subjected to investigation and after changes, the remaining group of buildings was also subjected to analysis. Buildings erected in single-family developments in Western Pomerania were analysed, namely: Szeroka Estate, Szczecin (fig. 9, tab. 10), Laurowe Estate (fig. 10, tab. 11), Tęczowe Estate, Stargard (fig. 11, tab. 12). This is primarily showcased by the result that makes it possible to compare the changes subjected to the base building while accounting for the different material solutions and the remodelling of its architectural form. 

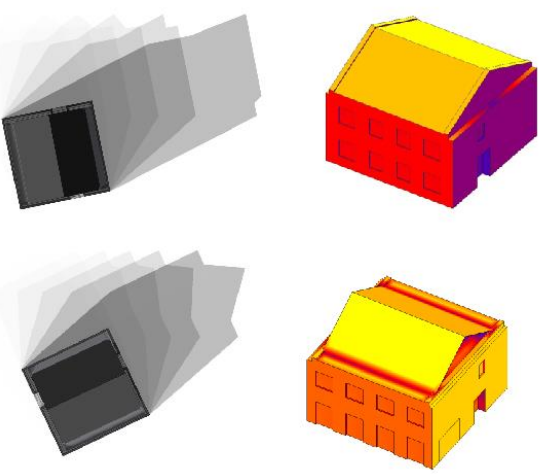

B
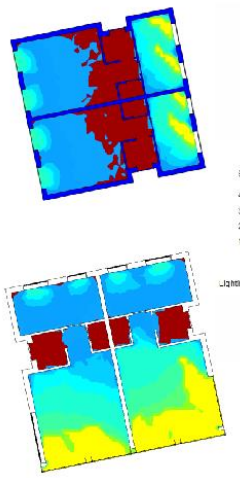

C
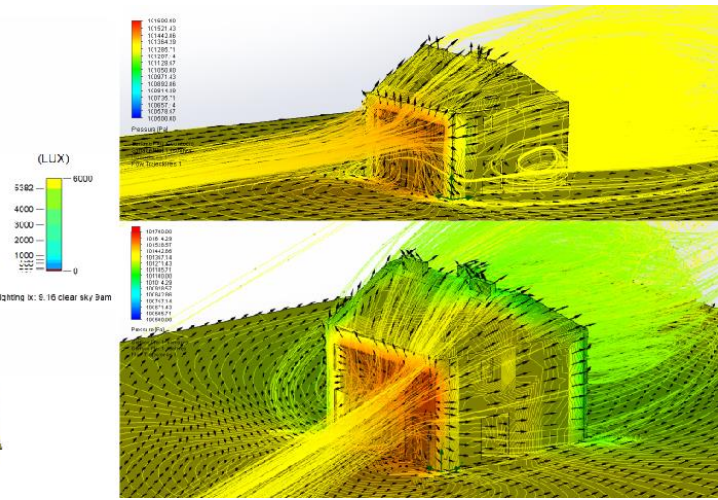

D

Fig. 9. At the top, the design before changes, at the bottom, the design after changes aimed at maximizing and minimizing the examined parameters. A: Building shadow cast analysis on March 21 and September 21; B: Analysis of the annual insolation of the building surface; C: Analysis of the annual daylight access to the rooms in the building - the analyzes were performed using: Autodesk: Ecotect Analysis; D: Analysis of the wind load of a single-family house. Changes aimed at minimizing the wind load on the structure of the building - analyzes were made using: Solidworks: Flow Simulation. Source: author

Ryc. 9. Od góry projekt przed zmianami, na dole projekt po zmianach mających na celu maksymalizację oraz minimalizację badanych parametrów. A: Analiza rzucania cienia przez budynek w dniach: 21 marca i 21 września; B: Analiza rocznego nasłonecznienia powierzchni budynku; C: Analiza rocznego dostępu światła dziennego do pomieszczeń w budynku - analiz dokonano przy użyciu: Autodesk: Ecotect Analysis; D: Analiza obciążenia wiatrem domu jednorodzinnego. Zmiany mające na celu minimalizację obciążenia wiatrem na strukturę budynku - analiz dokonano przy użyciu: Solidworks: Flow Simulation. Źródło: autor

Tab. 10. Analyzes of the building from Osiedle Szeroka in Szczecin. Analysis of the annual energy gains and losses of the building from passive gains from solar radiation - the analyzes were made using: Autodesk: Ecotect Analysis. Source: author

\begin{tabular}{|l|l|}
\hline Building before the changes & The building after changes \\
\hline Calculations of losses (-\%) and profits (+\%) for all thermal & Calculations of losses (-\%) and profits (+\%) for all thermal \\
zones of the building: from January 1 to December $31:$ & zones of the building: from January 1 to December $31:$ \\
SOL-AIR $+4.3 \%$, & SOL-AIR $+3.7 \%$, \\
SOLAR $+19.2 \%$, & SOLAR $+28.3 \%$, \\
VENTILATION $-70.9 \%$, & VENTILATION $-65.7 \%$, \\
INTERNAL $+75.5 \%$. & INTERNAL $+68.7 \%$. \\
\hline Energy demand $49,127 \mathrm{kWh} / \mathrm{m} 2 / \mathrm{rok}$. & Energy demand $66.769 \mathrm{kWh} / \mathrm{m} 2 / \mathrm{rok}$. \\
\hline
\end{tabular}
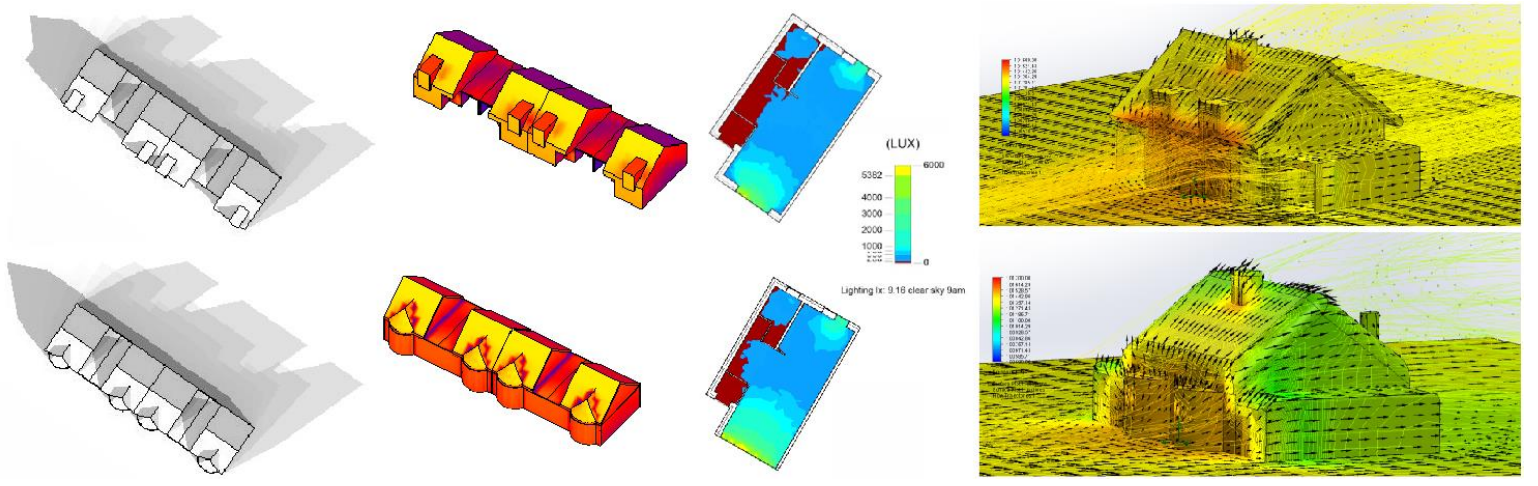

A

B

C

D

Fig. 10. At the top, the design before changes, at the bottom, the design after changes aimed at maximizing and minimizing the examined parameters. A: Building shadow cast analysis on March 21 and September 21; B: Analysis of the annual insolation of the building surface; C: Analysis of the annual daylight access to the rooms in the building - the analyzes were performed using: Autodesk: Ecotect Analysis; D: Analysis of the wind load of a single-family house. Changes aimed at 
minimizing the wind load on the structure of the building - analyzes were made using: Solidworks: Flow Simulation. Source: author

Ryc. 10. Od góry projekt przed zmianami, na dole projekt po zmianach mających na celu maksymalizacje oraz minimalizację badanych parametrów. A: Analiza rzucania cienia przez budynek w dniach: 21 marca i 21 września; B: Analiza rocznego nasłonecznienia powierzchni budynku; C: Analiza rocznego dostępu światła dziennego do pomieszczeń w budynku - analiz dokonano przy użyciu: Autodesk: Ecotect Analysis; D: Analiza obciążenia wiatrem domu jednorodzinnego. Zmiany mające na celu minimalizację obciążenia wiatrem na strukturę budynku - analiz dokonano przy użyciu: Solidworks: Flow Simulation. Źródło: autor

Tab. 11. Analyzes of the building from Osiedle Laurowe in Koszalin. Analysis of the annual energy gains and losses of the building from passive gains from solar radiation - the analyzes were made using: Autodesk: Ecotect Analysis. Source: author

\begin{tabular}{|l|l|}
\hline Building before the changes & The building after changes \\
\hline Calculations of losses (-\%) and profits (+\%) for all thermal & Calculations of losses (-\%) and profits (+\%) for all thermal \\
zones of the building: from January 1 to December $31:$ & zones of the building: from January 1 to December $31:$ \\
SOL-AIR $+5.9 \%$, & SOL-AIR $+5.4 \%$, \\
SOLAR $+21.1 \%$, & SOLAR $+26.8 \%$, \\
VENTILATION $-70.9 \%$, & VENTILATION $-68.6 \%$, \\
INTERNAL $+71.6 \%$. & INTERNAL + $66.1 \%$. \\
\hline Zapotrzebowanie energetyczne $88,293 \mathrm{kWh} / \mathrm{m} 2 /$ rok. & Zapotrzebowanie energetyczne $90,750 \mathrm{kWh} / \mathrm{m} 2 / \mathrm{rok}$. \\
\hline
\end{tabular}
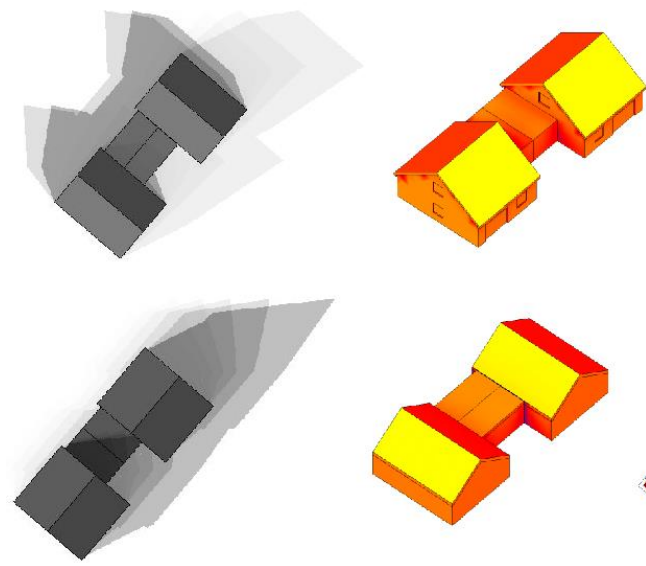

B

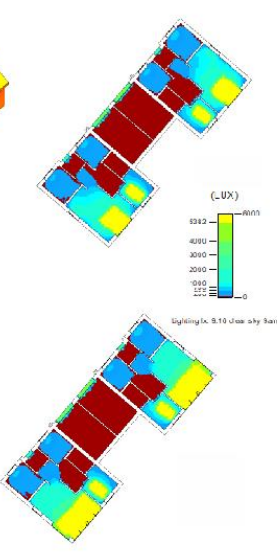

C

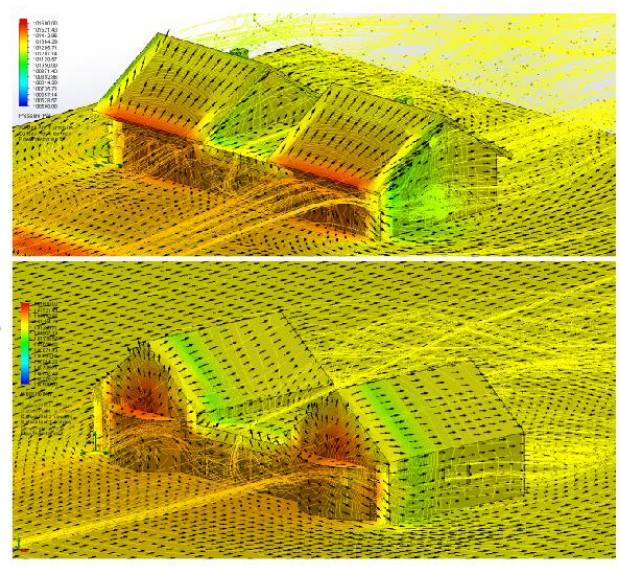

D

Fig. 11. At the top, the design before changes, at the bottom, the design after changes aimed at maximizing and minimizing the examined parameters. A: Building shadow cast analysis on March 21 and September 21; B: Analysis of the annual insolation of the building surface; C: Analysis of the annual daylight access to the rooms in the building - the analyzes were performed using: Autodesk: Ecotect Analysis; D: Analysis of the wind load of a single-family house. Changes aimed at minimizing the wind load on the structure of the building - analyzes were made using: Solidworks: Flow Simulation. Source: author

Ryc. 11. Od góry projekt przed zmianami, na dole projekt po zmianach mających na celu maksymalizację oraz minimalizację badanych parametrów. A: Analiza rzucania cienia przez budynek w dniach: 21 marca i 21 września; B: Analiza rocznego nasłonecznienia powierzchni budynku; C: Analiza rocznego dostępu światła dziennego do pomieszczeń w budynku - analiz dokonano przy użyciu: Autodesk: Ecotect Analysis; D: Analiza obciążenia wiatrem domu jednorodzinnego. Zmiany mające na celu minimalizację obciążenia wiatrem na strukturę budynku - analiz dokonano przy użyciu: Solidworks: Flow Simulation. Źródło: autor

Tab. 12. Analyzes of a building from Osiedle Tęczowe in Stargard. Analysis of the annual energy gains and losses of the building from passive gains from solar radiation - the analyzes were made using: Autodesk: Ecotect Analysis. Source: author

\begin{tabular}{|l|l|}
\hline Building before the changes & The building after changes \\
\hline Calculations of losses (-\%) and profits (+\%) for all thermal & Calculations of losses (-\%) and profits (+\%) for all thermal \\
\hline
\end{tabular}




\begin{tabular}{|l|l|}
\hline zones of the building: from January 1 to December $31:$ & zones of the building: from January 1 to December $31:$ \\
SOL-AIR $+5.9 \%$, & SOL-AIR $+5.6 \%$, \\
SOLAR $+19.3 \%$, & SOLAR $+21.8 \%$, \\
VENTILATION $-70.9 \%$, & VENTILATION $-70.1 \%$, \\
INTERNAL $+74.2 \%$ & INTERNAL $+71.8 \%$. \\
\hline Energy demand $67,605 \mathrm{kWh} / \mathrm{m} 2 /$ rok. & Energy demand $68,684 \mathrm{kWh} / \mathrm{m} 2 / \mathrm{rok}$. \\
\hline
\end{tabular}

The results presented in this paper, obtained using the abovementioned software, display the effects of passive solar energy obtainment-the energy losses and gains of buildings. Of note are the solar gains due to the proper placement of the building relative to the cardinal directions, and due to the form and type of development (detached, semi-detached or terraced). The analyses pertain to essential matters associated with the life cycle of single-family buildings. They indicate important issues and point to the necessity of conducting the design process in a manner that can maintain balance between the form and structure of the building and the energy consumed during the house's use.

\section{CONCLUSIONS}

The performance of a building, when investigated from the standpoint of sustainable development, should be assessed in terms of its impact on the natural environment, due to energy consumption and the emission of $\mathrm{CO} 2$. The material presented features an analysis of this issues in terms of construction materials and shaping architectural form. It is believed that buildings should be planned and designed so as to ensure maximum energy and material compensation, so that a building can exceed its planned service life. It is recommended to use the full capacity of the selection of pro-ecological materials with low GWP indicators and low embodied energy, which are locally sourced, easy to install and replace, etc. Afterwards, the proper shaping of the massing and its proper orientation relative to the cardinal directions is to ensure maximum passive heating, contributing to satisfying the building's energy demand across its entire life cycle. Both elements of the building's design significantly contribute to lowering CO2 emissions.

Studies have shown the advanced analytical aspect of computer applications in design and the role of LCA and BIM in meeting many aspects of design. They enable the analysis of various criteria within a virtual environment and allow the introducing of modifications so as to improve the design prior to its construction. This is the main reason why the analysis of the building (LCA and BIM) is even more precise than traditional methods. Implementing building performance analysis brings many benefits. Apart from significant improvements in the context of sustainable development, such as a reduction in $\mathrm{CO} 2$ emissions, lower energy demand and the performance of the building's form, it can also bring considerable short and long-term savings to users and maximise potential benefits in terms of impact on the natural environment. However, this implementation is not without its limitations. Implementing a new approach to the design of single-family houses requires changes in how architects work. For this to work, legal changes are necessary, along with introducing an obligation to perform multi-criteria BIM and LCA analyses during the design process.

Therefore, it should be assumed that, when starting work on a design, one should indicate the number of repetitions using LCA and BIM, calculate inputs and outputs concerning energy consumption and reducing $\mathrm{CO} 2$ emissions during the manufacture and application of construction materials in the structure of the building and the design of its architectural form, oriented to follow energy (form follows energy) (Cody, 2012), the environment (Badarnah, 2017), and energy as argued by Zacks (2008), etc. which can minimise the impact of the building on the environment. Optimising solutions and pursuing new techniques and technologies that strive to minimise the impact of architecture on the environment directs the exploration of the design process towards an architecture that adapts to global climate change. Key design decisions that account for all manners of determining (and minimising) impact on the natural environment using Life Cycle Assessment (which refer to energy and materials) clearly impact the architecture of single-family houses. 
Tab. 13. Factors influencing the architecture of single-family houses in Western Pomerania. Source: author

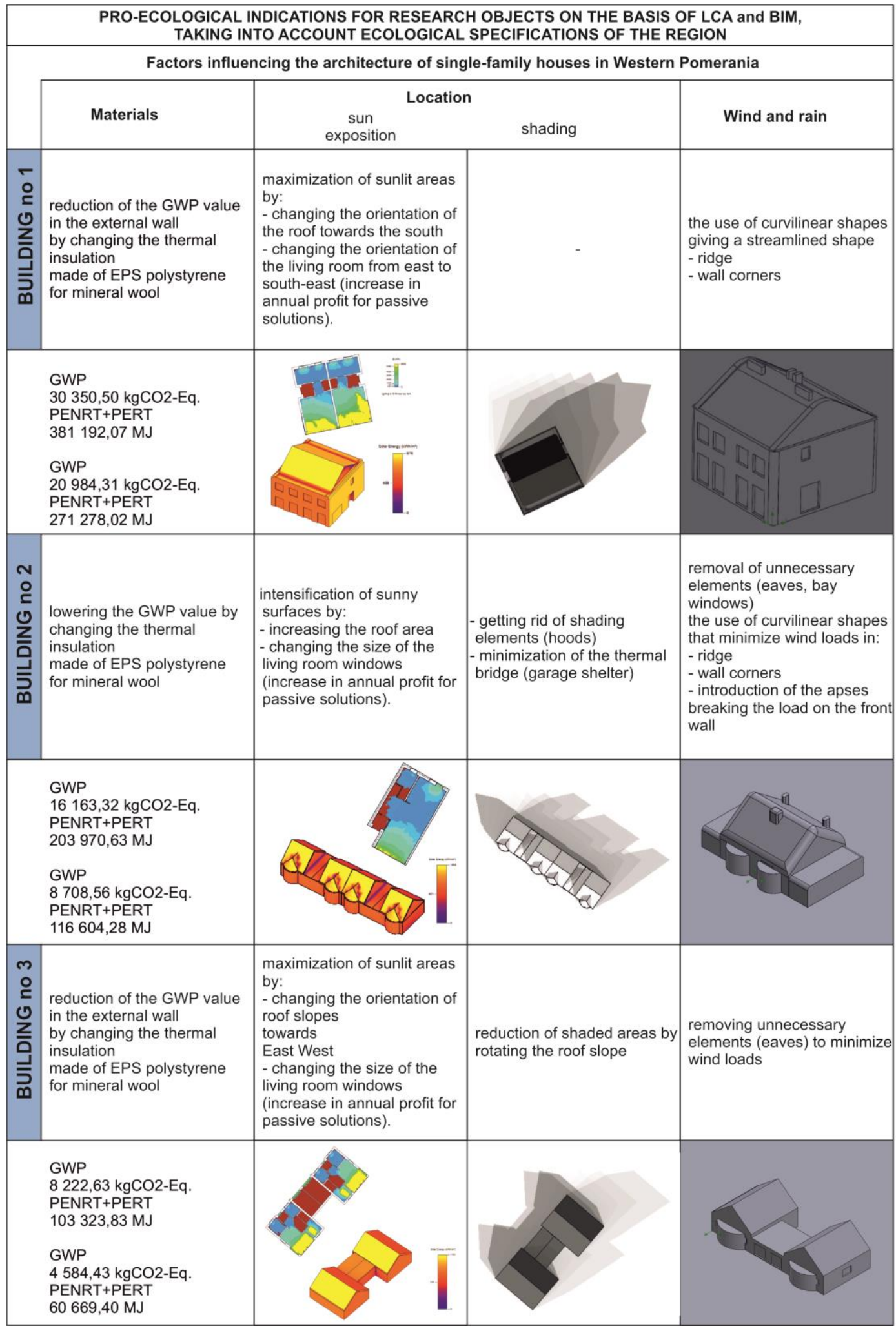

It should be highlighted that one cannot ignore the overlapping dependencies between structure, function and form in the pursuit of harmoniously designing a single-family house, wherein their 
relations and integration are summarised in a holistic perspective of the life cycle of the building being designed.

The proper design of a building's form is responsible for minimising negative impact over its entire life cycle. It is worth adding that selecting elements with high or low ecological indicators (CO2 absorption during manufacturing, embodied energy, etc.) also affect the aesthetic of the house. At the same time, the design of the form of the house should account for the climate of the site, which can affect said form. It is therefore necessary to identify factors that affect the architecture of single-family houses in Western Pomerania. These factors have been presented in the table below (tab. 13).

\section{ZASTOSOWANIE METOD LCA ORAZ BIM W ARCHITEKTURZE DOMU JEDNORODZINNEGO W ZMIENIAJACYM SIĘ KLIMACIE POMORZA ZACHODNIEGO}

\section{WSTĘP}

Celem artykułu jest poszukiwanie zmian w paradygmacie architektonicznym projektowania domów jednorodzinnych oraz zastosowaniem odpowiednich rozwiązań technicznych minimalizujących oddziaływanie budynków na środowisko naturalne. Problem optymalizacji energetycznej budownictwa i architektury jest istotny ze względu na zmieniający się klimat i jego późniejsze konsekwencje w projektowaniu architektury.

W pierwszej części przybliżono klimat występujący w regionie Pomorza Zachodniego. Przedstawiono aktualne i prawdopodobne nieodwracalne zmiany regionu, takie jak nasilenie wiatru lub formowanie się równin zalewowych. Następnie scharakteryzowano występującą zabudowę jednorodzinną na badanym obszarze.

W drugiej części przedstawiono metodę Analizy i Oceny Cyklu Życia (ang. Life Cycle Assessment, $L C A$ ) oraz modelowania informacji o budynku (ang. Building Information Modeling, BIM).

Część analityczna metody LCA została ograniczona okresem życia (RSL) 100 lat. Obliczenia bazują na autorskim kalkulatorze. Wykonywane są na podstawie danych z deklaracji środowiskowych produktu (EPD). Wyniki obrazują współczynnik ocieplenia globalnego (GWP) i konsumpcję energii pierwotnej (PE) materiałów budowlanych użytych w strukturze budynku. Wskazuje się odpowiedni dobór materiału budowlanego minimalizującego negatywny wpływ na środowisko. Analizy wykonane zostały w jednostkach: $\mathrm{kgCO}_{2} \mathrm{eq}$. i MJ.

W części analitycznej metod BIM wskazano na celowość obliczeniową aktualnie projektowanych form architektonicznych budynków, występujących na badanym obszarze. Badania obrazują kształtowanie formy architektonicznej z wykorzystaniem efektywnych czynników środowiskowych i klimatycznych. Prowadzi to do optymalizacji kształtu budynku. Badania wykonane zostały w kontekście analiz: rzucania cienia przez budynek; rocznego nasłonecznienia powierzchni budynku; rocznego dostępu światła dziennego do pomieszczeń w budynku; obciążenia wiatrem domu jednorodzinnego (przy prędkości przepływu powietrza w zakresie $25 \mathrm{~m} / 2-90 \mathrm{~km} / \mathrm{h}$ ), oraz rocznych zysków i strat energetycznych budynku z zysków biernych z promieni słonecznych.

Wyniki badań charakteryzują zmiany zachodzące w strukturze i architekturze budynków domów jednorodzinnych. Wskazuje się słuszność nowego podejścia do kształtowania formy architektonicznej i doboru materiałów budowlanych stosowanych w domach jednorodzinnych na badanym obszarze mając na uwadze zrównoważony rozwój architektury i branży budowlanej w erze zmieniającego się klimatu Antropocenu. 


\section{CHARAKTERYSTYKA POMORZA ZACHODNIEGO}

Pomorze Zachodnie jest terenem o bogatej historii i walorach przyrodniczych. Historia określała granice tego obszaru od wieków. Krzyżowały się na tym obszarze interesy Polski, Brandenburgii, Państwa Zakonnego, Meklemburgii, Szwecji, Danii i Cesarstwa Niemieckiego. Obecnie granice historycznego Pomorza Zachodniego wyznaczają między innymi województwo zachodniopomorskie i część województwa pomorskiego oraz północno-wschodnia część Vorpommern w Niemczech.

Podpisanie umowy 15 grudnia 1995 roku zapoczątkowało Utworzenie Euroregionu Pomerania, w której określono za cel podejmowanie wspólnych działań dla równomiernego i zrównoważonego rozwoju regionu oraz zbliżenia jego mieszkańców po obu stronach granicy.

\subsection{Charakterystyka środowiska naturalnego na obszarze Pomorza Zachodniego}

Pomorze Zachodnie posiada zróżnicowane właściwości ekologiczne oraz pogodowe. Fakt ten jest ważny ze względu na charakter właściwego projektowania architektury dostosowanego do danego obszaru oraz występującego tam klimatu i ekosystemu mając na uwadze m.in. na względy pogodowe. Określić należy czynniki środowiskowe, takie jak: usytuowanie i ekspozycji słonecznej oraz zacieniania, czy obciążenia obiektu wiatrem, powodujące właściwości oraz późniejsze cechy ekologicznej formy architektonicznej.

W programie ochrony środowiska województwa zachodniopomorskiego na lata 2016-2020 z perspektywą do 2024 (Program ochrony środowiska, 2016) zawarto zapis, że klimat województwa zachodniopomorskiego jest bardzo zróżnicowany. W pasie nadmorskim występuje klimat umiarkowany, ciepły morski, natomiast w głębi lądu umiarkowany, ciepły przejściowy. Zróżnicowanie klimatu występuje ze względu na ścieranie się w jego obrębie wpływów klimatu morskiego i lądowego, a także wpływu czynników lokalnych. Dlatego w regionie wyróżniono 10 krain klimatycznych. W głąb lądu i w kierunku wschodnim klimat lokalny zmienia się, pojawiają się wyższe temperatury latem i niższe zimą oraz znaczne amplitudy temperatur w ciągu dnia. Nagłe wahania temperatury są główną przyczyną występowania ekstremalnych zjawisk pogodowych.

Ze względu na zróżnicowane warunki klimatyczne oraz fizjograficzne obszar województwa zachodniopomorskiego został podzielony na dziesięć krain klimatycznych (Koźmiński, Michalska, Czarnecka, 2007).

Charakterystyka obszaru nadaje badaniu wymiar fizyczny. Występujące charakterystyczne cechy dla tego regionu są istotne dla prowadzonych analiz w koncepcji domu jednorodzinnego. Ważnym elementem dla kształtowania przyszłego budynku jest częste występowanie gwałtownych burz i wiatrów huraganowych (POGODA, 2020). Przytoczyć można, iż w 2019 roku zanotowano porywy wiatru: Szczecin $91 \mathrm{~km} / \mathrm{h}$, Koszalin 91,8 km/h, Kołobrzeg $112 \mathrm{~km} / \mathrm{h}$. Wiatr na przykład jest istotnym czynnikiem klimatycznym, który powoduje zmianę w podejściu do projektowania budynku uwzględniając właściwości ekologiczne dla formy architektonicznej. Należy przyjąć że wartości te będą utrzymywały się na podobnym poziomie lub rosły. Wskazać można że dane dotyczące porywów wiatru dostępne są między innymi na stronie www.irena.masdar.ac.ae.

Zauważyć należy, że zmieniający się klimat na całym świecie jest odczuwalny, a konsekwencje tego stanu rzeczy wpłyną na kształt analizowanego obszaru. Poniżej dla zobrazowania stanu rzeczy przestawiono mapy obszarów zalewowych (ryc. 1).

Zauważyć należy, iż obawy dotyczące zmian klimatycznych w obszarze miast w Polsce zostały zawarte w projektach planów adaptacji do zmian klimatu. Dla miasta Szczecin wskazuje się główne zagrożenia wynikające ze zmian klimatu, takie jak: średnie zagrożenie wzrostu poziomu morza, czy duże zagrożenie silnym i bardzo silnym wiatrem, burzami (w tym burze z gradem), oraz falami upałów (BIP, 2018, s. 31).

Kolejnym aspektem w projektowaniu na jaki należy zwrócić uwagę jest występowanie bogatej sfery przyrodniczej na obszarze województwa zachodniopomorskiego. Obszar ten należy scharakteryzować ze względu na występowanie, między innymi: wód powierzchniowych, Parków Narodowych, parków krajobrazowych, rezerwatów przyrody, oraz występujących pojedynczo obszarów przyrodniczo-krajobrazowych (Kępka, Kępka, Kępka, 2013). 
Charakterystyka środowiska naturalnego jest ważna z uwagi na prowadzenie procesu projektowego uwzględniającego równowagę względem występujących czynników klimatycznośrodowiskowych. Negatywne oddziaływanie budownictwa na środowisko naturalne skutkuje zmieniającym się klimatem. Tym samym, zmieniający się klimat wpływa na kształt i funkcjonowanie architektury. Możliwe jest poddanie architektury licznym analizom: rozpoznaniu, przeanalizowaniu i znalezieniu optymalnego rozwiązania na bazie wielokrotności powtórzeń, kalkulacji wejść i wyjść już w początkowej fazie procesu projektowego na ekranie komputera (

Tab.2).

Tab.2. Korzyści z prowadzenia analiz za pomocą cyfrowych narzędzi analitycznych. Źródło: opracowanie własne autora

\begin{tabular}{|c|c|c|}
\hline \multicolumn{3}{|c|}{ Korzyści z prowadzenia analiz za pomocą cyfrowych narzędzi analitycznych } \\
\hline $\begin{array}{l}\text { Element środowiska, } \\
\text { składowa środowiska } \\
\text { zbudowanego }\end{array}$ & Czynnik & $\begin{array}{l}\text { Wnioski z analiz umożliwiają działania świadomego kształtowania tkanki } \\
\text { miejskiej oraz budynków pod wpływem czynników egzogennych. } \\
\text { Rozwiązania projektowe osiągają pełen wymiar w kontekście zdrowia czło- } \\
\text { wieka ze względu na zmiany klimatyczne poprzez analizy parametrów wejść } \\
\text { i wyjść. }\end{array}$ \\
\hline Światło & $\begin{array}{l}\text { susza } \\
\text { nadmiar } \\
\text { cień }\end{array}$ & $\begin{array}{l}\text { Prawidłowe formowanie obiektów pasywnych i wykorzystujących odnawialne } \\
\text { źródła energii. } \\
\text { Znalezienie oraz zachowanie optymalnych odległości między obiektami umożli- } \\
\text { wiając minimalizację cienia oraz penetrację światła naturalnego. } \\
\text { Ochrona przez nadmiarem światła. }\end{array}$ \\
\hline Wiatr & $\begin{array}{l}\text { brak } \\
\text { huragany }\end{array}$ & $\begin{array}{l}\text { Znalezienie odpowiednich lokalizacji dla obiektów wykorzystujących odnawialne } \\
\text { źródła energii. } \\
\text { Zminimalizowanie lub wykształcenie korytarzy wiatrowych. }\end{array}$ \\
\hline Woda & $\begin{array}{l}\text { powodzie } \\
\text { susza }\end{array}$ & Formowanie budynków mogących zbierać wody deszczowe. \\
\hline Dźwięk & nadmiar & $\begin{array}{l}\text { Formowanie budynków i przestrzeni wokół, w celu zmniejszenia negatywnego } \\
\text { wpływu na percepcję człowieka (ang. soundscape). }\end{array}$ \\
\hline
\end{tabular}

Odpowiednia analiza i kwalifikacja wyników, umożliwia obliczanie danych nadających właściwy optymalny parametryczny rezultat formie architektonicznej oraz urbanistycznej. Prowadzenie procesu projektowego integrującego i implementującego analizy (z wykorzystaniem metodologii LCA i BIM) dla przyszłych terenów (miejskich) pod względem światła, dźwięku i wiatru, daje asumpt do podejmowania późniejszych prawidłowych decyzji projektowych w skali urbanistycznej i architektonicznej wpływających na kondycję środowiska zbudowanego i naturalnego.

\subsection{Charakterystyka środowiska zbudowanego na obszarze Pomorza Zachodniego}

Euroregion Pomerania zajmuje powierzchnię ok. 41 tys. $\mathrm{km}^{2} \mathrm{i}$ jest zamieszkiwany przez ponad 3,4 mln mieszkańców. Część Polską tworzy Stowarzyszenie Gmin Polskich Euroregionu Pomerania, w którego skład wchodzi większość gmin województwa Zachodniopomorskiego. Najważniejszymi ośrodkami miejskimi powyżej 50 tysięcy mieszkańców (stan na grudzień 2015 roku) na terenie Euroregionu Pomerania, są: Szczecin 405 657, Koszalin 107 970, Słupsk 92 496, Stargard 68670.

Dane te są ważne z uwagi na określenie ilości i jakości zasobów mieszkaniowych budownictwa jednorodzinnego oraz zdiagnozowanie pod względem ilości skonsumowanej materii: materiałów, energii, niezbędnej do poprawnego działania obiektów architektonicznych, środowiska zamieszkania. Zamknięta forma domu umożliwia analizy określające oddziaływania w kontekście emisji: gazów cieplarnianych (m.in. GWP), konsumpcji energetycznej (kWh), ale również potencjału absorbcji zanieczyszczeń (sekwestracja $\mathrm{CO}_{2}$ ), bioretencji i akumulacji zasobów, nadprodukcji energii odnawialnej (energia + ). 
Należy wskazać, że w latach 2009-2019 na terenie województwa zachodniopomorskiego grunty zabudowane i zurbanizowane zwiększyły swoją powierzchnie: z 96156 ha do 102575 ha, podobnie jak tereny mieszkaniowe: z 10697 ha do 13111 ha.

Budynki jednorodzinne wznoszone na obszarze Pomorza Zachodniego są, z punktu widzenia materiału udostępnionego przez Główny Urząd Statystyczny, niemożliwe do scharakteryzowania pod względem technologii wznoszenia, a tym samym ilości użytych materiałów budowlanych. Jednakże wizja lokalna oraz informacji ze strony internetowej GUS (GUS), można stwierdzić, że są to w większości domy wznoszone w technologii tradycyjnej udoskonalonej. Główne elementy takich budynków można scharakteryzować jako typowe, w których najczęściej występują następujące rozwiązania konstrukcyjne: fundament: ławy fundamentowe i posadzka na gruncie lub fundament płytowy, ściany nośne: bloczki z betonu komórkowego lub pustaki ceramiczne, nadproża: strunobetonowe lub żelbetowe, stropy: gęstożebrowe lub monolityczne, dach wysoki: w konstrukcji drewnianej.

Przeprowadzono analizy wybranych osiedli mieszkaniowych domów wolnostojących w zabudowie jednorodzinnej w obszarze województwa zachodniopomorskiego. Wykazać należy brak poszukiwań formy podążającej za środowiskiem. Elementami określającymi (w pewnym sensie) formę oraz estetykę budynków są przesłanki, wynikające z zapisów miejscowego planu zagospodarowania przestrzennego lub wydanej decyzji o warunkach zabudowy i zagospodarowania terenu. Zabudowa jednorodzinna osiedli mieszkaniowych na terenie województwa zachodniopomorskiego, charakteryzuje się zastosowaniem typowych rozwiązań konstrukcyjno-materiałowych występujących na terenie Polski. Materiały budowlane w strukturze tych budynków są obecnie powszechnie stosowane. Zaliczyć do nich można następujące rozwiązania: w ścianach zewnętrznych z bloczków betonu komórkowego pokrytego styropianem, tradycyjnej konstrukcji fundamentów, dachu, oraz stolarce okiennej PCV. Przyjęte rozwiązania materiałowe nie wskazują na ich ekologiczny charakter.

Najczęstszą formą domu jednorodzinnego na terenie Pomorza Zachodniego jest bryła zbliżona do sześcianu z wysokim dwu, cztero, lub wielospadowym dachem. Powierzchnia działki waha się w granicach $800-1200 \mathrm{~m}^{2}$, a powierzchnia zabudowy wynosi $30-40 \%$ całej działki. Jednakże, tendencje w budowie formy architektonicznej domów jednorodzinnych nie tylko na Pomorzu Zachodnim są wypadkową indywidualnej kreatywności inwestorów. W ustawie o planowaniu i zagospodarowaniu przestrzennym z dnia 27 marca 2003 roku został zdefiniowany termin „ład przestrzenny”. Kierując się znaczeniem tego terminu można by domniemać, że nowoprojektowane i powstające budynki będą tworzyć harmonijną całość m.in. kompozycyjno-estetyczną. Jednak niewystarczająca ilość miejscowych planów zagospodarowania przestrzennego (w Szczecinie obejmują one aktualnie $59,46 \%$ obszaru) (BIP, 2020) oraz wydawane decyzje o warunkach zabudowy są elastyczne i umożliwiają tym samym zauważalną i dotkliwą swobodę w kreacji architektonicznej o niskich walorach estetycznych.

\section{ANALIZA I OCENA CYKLU ŻYCIA ORAZ MODELOWANIE INFORMACJI O BUDYNKU DOMÓW JEDNORODZINNYCH}

Zasoby mieszkaniowe na analizowanym obszarze Pomorza Zachodniego to istniejąca forma materialna (domy), cechująca się relatywną konsumpcją energetyczną oraz zawartymi w niej materiałami (substancją i energią). Analizie poddano wolnostojące domy jednorodzinne w istniejącej zabudowie. Uwzględniając budowę i funkcjonowanie domu, przeprowadzone analizy odpowiadają na pytanie: jaki wpływ na ekosystem wywiera badany budynek oraz cały zespół obiektów architektonicznych, wskazując na emisję $\mathrm{CO}_{2}$ z nieodnawialnych źródeł energii (gazu, węgla, oleju). Szacuje się w ten sposób ilość energii wbudowanej, która jest odpowiedzialna za szkodliwą emisję w cyklu życia produktów budowlanych od wydobycia surowców, poprzez produkcję, transport aż do wbudowania w strukturę budynku. Obecnie nauka i technika nastawiona jest na obniżenie konsumpcji z nieodnawialnych źródeł energii w budownictwie (niezbędnej do jej poprawnego funkcjonowania). Dlatego ważna jest minimalizacja udziału energii wbudowanej podczas pełnego cyklu trwania (materiałów) budynku, która powinna być świadomie obniżana w stosunku do emisji eksploatacyjnej 
budynku. Daje to możliwość zobrazowania ich wpływu na ekosystem. Założyć należy konieczność podejmowania zrównoważonych decyzji projektowych mających zminimalizować oddziaływanie budynku na przyrodę $w$ cyklu jego istnienia.

Zaznaczyć należy, że współcześnie budowa domu powoduje w dużej mierze określoną ilość negatywnego oddziaływania $\left(\mathrm{CO}_{2}\right)$ oraz konsumpcji: energii, wody oraz surowców naturalnych. Projektowanie i budowanie domów jednorodzinnych, prowadzić powinno do poszukiwania rozwiązań w sferze budynków: energooszczędnych, niskoenergetycznych i proekologicznych. Obiekty takie systematyzuje się jako budynki: inteligentne, niskoemisyjne $\mathrm{CO}_{2}$, pasywne, zero lub plus energetyczne, które charakteryzuje całościowe podejście do projektowania, eksploatacji i cyklu życia budynku (Przesmycka, 2012, Czarnecki, Rytel, 2013). Ten ostatni interesujący nas element powinien zaistnieć ustawowo ze strony prawodawcy (obecnie wprowadzono jedynie Analizę Kosztów Życia LCC, która odnosi się tylko do Ustawy Prawo Zamówień Publicznych) przy projektowaniu domów jednorodzinnych, tak aby w przyszłości indywidualne budownictwo mieszkaniowe sprostało wymaganiom zawartym w idei zrównoważonego rozwoju. Z przeprowadzonych analiz zabudowy, do określenia wpływu zabudowy jednorodzinnej na środowisko istotne jest wskazanie energochłonności w cyklu życia budynków, by poznać ich pełny wpływ na środowisko. Zgodzić się należy z wnioskami Sarosiek i Sadowskiej (Sarosiek, Sadowska, 2009), które wskazują, iż minimalizacja energii powinna dotyczyć wszystkich widocznych etapów. Jednak, jeśli całkowitą energię zużywaną na cały cykl życia uznamy za 100\%, to wytwarzanie materiałów i wzniesienie budynku stanowi 10$12 \%$, remonty i rozbiórka ok. 5\%, natomiast użytkowanie to aż $83-85 \%$ tej energii. Autorzy ci charakteryzują zmianę szacunkowych wartości wskaźnika zapotrzebowania na ciepło do ogrzewania na przestrzeni lat.

Zauważyć należy, że najważniejsze decyzje projektowe są podejmowane i realizowane $\mathrm{w}$ fazie koncepcyjnej i mają one bezpośredni wpływ na charakterystykę energetyczną zaprojektowanego budynku. W fazie koncepcyjnej potrzebne są proste metody oraz szybkie odpowiedzi, dotyczące oceny porównawczej zaproponowanych pomysłów i koncepcji architektonicznych. Między innymi, zapotrzebowanie na energię cieplną budynku jest wynikiem zarówno wyborów technicznych jak i architektonicznych dokonywanych we wstępnym procesie projektowym. Do rozwiązań projektowych wpływających na zapotrzebowanie na energię cieplną (rzutujące na zyski i straty ciepła budynku) zaliczyć można decyzje projektowe, wpływające także na sam projekt architektoniczny, takie jak: lokalizacja, orientacja budynku względem stron świata; kształt budynku; usytuowanie oraz powierzchnia drzwi i okien; zastosowane materiały w strukturze (ang. skin and bones) budynku.

\subsection{Analiza metodą LCA oraz BIM elementów i struktury domów jednorodzinnych na Pomorzu Zachodnim}

Analizie i Ocenie Cyklu Życia poddano dom jednorodzinny wolnostojący pod względem wpływu na środowisko naturalne materiałów budowlanych zastosowanych $w$ jego strukturze. Badanie polegało na przygotowaniu przez autora kalkulatora w programie Microsoft Excel ${ }^{2}$ i wprowadzeniu danych z Deklaracji Środowiskowej Produktu - EPD (ang. Environmental Product Declaration). Deklaracje Środowiskowe Produktu zawierają w swej formule określoną przydatność wyrobu, tym samym wyniki pokazują sumę przypadającą na ewentualne remonty, tj. wymianę materiałów wynikającą z Żywotności Referencyjnej - RSL (ang. Reference Service Life). W rezultacie obliczono wpływ materiałów budowlanych budynku, na środowisko w pełnym zakładanym cyklu życia (100 lat). Dzięki temu oszacowano jak duży jest wpływ materiałów budowlanych na środowisko naturalne w całej strukturze budynku pod względem istotnych informacji, parametrów oraz z założeniem cezury czasowej jego funkcjonowania; na co składa się: Potencjał tworzenia efektu cieplarnianego - GWP (ang. Global Warming Potential); Całkowite wykorzystanie nieodnawialnych zasobów ener-

\footnotetext{
${ }^{2}$ Autor przygotował własny kalkulator dla zachowania wiarygodności obliczeń, ponieważ darmowe oprogramowanie LCA udostępnia i umożliwia obliczenia według wartości szacunkowych lub ujednoliconych. Dlatego aby mieć rzeczywiste wartości produktów posłużono się konkretnymi deklaracjami środowiskowymi produktów (EPD) z platform internetowych: Źródło: http://www.environdec.com, http://www.knaufinsulation.com/, http://www.epd-online.com, http://www.ibu-epd.com/ (dostep: 01.11.2017)
} 
gii pierwotnej - PENRT (ang. Total use of non renewable primary energy resources); Całkowite wykorzystanie odnawialnych zasobów energii pierwotnej - PERT (ang. Total use of renewable primary energy resources); Wykorzystanie świeżej wody netto - FW (ang. Use of net fresh water); Odpady nie stwarzające zagrożenia - NHWD (ang. Non hazardous waste disposed), Unieszkodliwione odpady niebezpieczne - HWD (ang. Hazardous waste disposed); Unieszkodliwione odpady radioaktywne - RWD (ang. Radioactive waste disposed), Materiały do ponownego użycia - CRU (ang. Components for re-use); Materiały do recyklingu - MFR (ang. Materials for recycling); Materiał do odzysku energii - MER (ang. Materials for energy recovery). Należy jednak przyjąć prawdopodobny błąd obliczeniowy, wynikający z konceptualnego / uproszczonego charakteru analiz.

W pierwszym etapie ocenie poddano teren obejmujący zabudowę z powtarzalnymi, ze względu na zamknięty charakter osiedla, domami jednorodzinnymi. Na obszarze tym, zanalizowano korzyści, wynikające z ukształtowania formy architektonicznej pod względem energetycznym.

W drugim etapie określono charakterystykę współczynnika przenikalności cieplnej „U” dla przegród w budynku, w dwóch przedziałach: pierwszy przypadł na okres budowy 1933 rok, drugi to spełniający aktualne wymagania, wynikające z norm i warunków technicznych. Dodatkowo poszerzono sporządzoną analizę o wpływ konstrukcji lekkiej-drewnianej na środowisko. Przeprowadzone analizy formy budynku z policzonym współczynnikiem „U” pomogły w określeniu korzyści z ukształtowania formy obiektu, która mogłaby (ale nie musiała) maksymalnie czerpać zyski pasywne z promieniowania słonecznego.

W trzecim etapie - referencyjny dom poddano Analizie Cyklu Życia zastosowanych materiałów budowlanych pod względem ich wpływu na środowisko naturalne, biorąc pod uwagę elementy LCA przed użytkowaniem (ang. Before Use), podczas użytkowania (ang. Use), po użytkowaniu - koniec życia (ang. End of Life), korzyści i obciążenia poza granicami systemu (ang. Benefits and loads beyond the system boundaries). Na zakończenie wskazano procentowy udział zastosowanych materiałów budowlanych w strukturze budynku, elementów pod kątem konsumpcji energetycznej (PENRT+PERT) oraz wpływ na efekt cieplarniany (GWP).

Następnie te same budynki poddano analizie w specjalistycznym oprogramowaniu z narzędziami BIM. Badaniu, z wykorzystaniem analitycznych narzędzi cyfrowych, poddano wolno stojące domy jednorodzinneBłąd! Nie można odnaleźć źródła odwołania.. W pierwszej kolejności przeprowadzono analizy: rzucanego cienia przez budynek w dniach: 21 marca i 21 września w godzinach 1014, rocznego nasłonecznienia powierzchni budynku i rocznego dostępu światła dziennego do pomieszczeń w budynku. Badania przy użyciu oprogramowania, określają ilość konsumowanej energii konwencjonalnej niezbędnej do funkcjonowania budynku (obiektu) oraz możliwości biernego pozyskiwania energii słonecznej - zysków i strat energetycznych budynków z wyszczególnieniem czterech parametrów: Sol-Air - zyski wynikające z pośredniego działania promieni słonecznych na eksponowane materiały budowlane; Solar - bezpośrednie zyski ciepła z wnikających do wnętrza promieni słonecznych. Zyski wynikające z przezroczystych powierzchni (okna i okna dachowe), podczas gdy Sol-Air odnosi się do zysków za pośrednictwem nieprzezroczystych powierzchni; Wentylacja - to zyski i straty wynikające z wentylacji i infiltracji; Wewnętrzne - wewnętrzne zyski ze sztucznego oświetlenia, przebywania ludzi i sprzętu elektrycznego.

Poniżej przedstawia się wyniki badań metodą LCA oraz BIM.

\subsubsection{Analiza metodą LCA}

W pierwszej kolejności, jako przykład bazowy, przebadano budynek z 1933 roku (tab. 2, ryc. 2). W drugim etapie przebadano taki sam budynek spełniający parametry określone w Warunkach Technicznych z 2017 roku (tab. 3, ryc. 3). Przebadano również budynek wzniesiony w technologii szkieletowej drewnianej spełniający obowiązujące Warunki Techniczne (tab. 4, ryc. 4). Obrazuje to przede wszystkim zmiany jakie obiekt bazowy przeszedł uwzględniając zastosowane różne materiały budowlane. $\mathrm{W}$ tej samej formule zostały przebadane obecnie wznoszone domy $\mathrm{z}$ osiedli w zabudowie jednorodzinnej na obszarze Pomorza Zachodniego: Osiedle Szeroka, Szczecin (tab. 5, ryc. 5), Osiedle Laurowe, Koszalin (tab. 6, ryc. 6), Osiedle Tęczowe, Stargard (tab. 7, ryc. 7). 
Przeprowadzone analizy obrazują jak obiekt architektoniczny (w tym wypadku wolno stojący dom jednorodzinny) oddziałuje na środowisko oraz w jaki sposób analiza przeprowadzona w specjalistycznym oprogramowaniu umożliwia określenie jego wpływu na środowisko naturalne. Umożliwiło to detekcję materiałów budowlanych wpływających na środowisko naturalne oraz ich zmianę. W tym przypadku dotyczy to ścian zewnętrznych (tab. 8).

Tab. 8. Zmiany materiałów budowlanych w strukturze ścian zewnętrznych wg obliczeń Analizy Cyklu Życia. Źródło: Opracowanie autora.

\begin{tabular}{|l|l|l|l|}
\hline & Budynek nr 1 & Budynek $\mathrm{nr} 2$ & Budynek nr 3 \\
\hline \multirow{5}{*}{ Przed zmianami } & GWP & GWP & GWP \\
& $30350,50 \mathrm{kgCO}_{2}$-Eq. & $16163,32 \mathrm{kgCO}_{2}$-Eq. & 8 222,63 $\mathrm{kgCO}_{2}$-Eq. \\
& PENRT+PERT & PENRT+PERT & PENRT+PERT \\
& $381192,07 \mathrm{MJ}$ & $203970,63 \mathrm{MJ}$ & $103323,83 \mathrm{MJ}$ \\
\hline \multirow{5}{*}{ Po zmianach } & $\mathrm{GWP}$ & $\mathrm{GWP}$ & $\mathrm{GWP}$ \\
& $20984,31 \mathrm{kgCO}_{2}$-Eq. & $8708,56 \mathrm{kgCO}_{2}$-Eq. & $4584,43 \mathrm{kgCO}_{2}$-Eq. \\
& PENRT+PERT & PENRT+PERT & PENRT+PERT \\
& $271278,02 \mathrm{MJ}$ & $116604,28 \mathrm{MJ}$ & $60669,40 \mathrm{MJ}$ \\
\hline
\end{tabular}

Analizy umożliwiają a priori wskazanie: jak budować obiekt, jakich materiałów użyć, jak tworzyć formę obiektu architektonicznego, tak aby jak najlepiej wykorzystywała dobra natury, tj. słońce, wiatr, wodę, ukształtowanie terenu, itd. Ten model pracy w oprogramowaniu daje racjonalne wyni$\mathrm{ki}$, które pod względem estetyczno-ekologicznym są cenne $z$ uwagi na proekologiczny charakter rozwiązań. Powoduje to równocześnie znikomą potrzebę wprowadzania zmian w budynku a posteriori.

\subsubsection{Analiza metodą BIM}

Przeanalizowano większość zagadnień związanych z funkcjonowaniem budynku, jako obiektu architektonicznego w środowisku. W skład analiz wchodzi: Analiza rzucania cienia przez budynek w dniach: 21 marca i 21 września; Analiza rocznego nasłonecznienia powierzchni budynku; Analiza rocznego dostępu światła dziennego do pomieszczeń w budynku - analiz dokonano przy użyciu: Autodesk: REVIT, Ecotect Analysis; Analiza obciążenia wiatrem domu jednorodzinnego - analiz dokonano przy użyciu: Solidworks: Flow Simulation; Analiza rocznych zysków i strat energetycznych budynku z zysków biernych z promieni słonecznych. Obliczenia strat $(-\%)$ oraz zysków $(+\%)$ dla wszystkich stref termicznych budynku: od 1 stycznia do 31 grudnia - analiz dokonano przy użyciu: Autodesk: Ecotect Analysis.

Pierwszym analizowanym budynkiem był ponownie budynek bazowy z początku XX wieku. Zaznaczyć należy, że określono sposób rzucania cienia własnego, ilości (natężenia) światła dziennego, dostającego się do wnętrza w ciągu roku oraz ilość energii słonecznej padającej na powierzchnie budynku elementy, które są możliwe do wykorzystania pod względem instalacji technologii pozyskiwania energii w sposób aktywny, pasywny, kompilacyjny. Ponadto, w przeprowadzonej analizie obciążenia budynku wiatrem, na modelu cyfrowym wprowadzono zmiany w kształcie mając na uwadze minimalizację wpływ wiatru na strukturę budynku (ryc. 8).

W analizie rocznych zysków i strat energetycznych budynku z zysków biernych z promieni słonecznych przeprowadzono na budynku bazowym z 1933 roku. Następnie dla porównania przebadano ten sam budynek spełniający parametry określone w Warunkach Technicznych z 2017 roku; budynek wzniesiony $w$ technologii szkieletowej drewnianej spełniający obowiązujące Warunki Techniczne; oraz budynek spełniający wymogi domu pasywnego (tab. 9).

Tab. 9. Analiza rocznych zysków i strat energetycznych budynku z zysków biernych z promieniowania słonecznego - analiz dokonano przy użyciu: Autodesk: Ecotect Analysis. Źródło: autor

\begin{tabular}{|l|l|l|l|}
$\begin{array}{l}\text { Budynek bazowy z 1933 } \\
\text { roku }\end{array}$ & $\begin{array}{l}\text { Budynek spełniający wymo- } \\
\text { gi Warunków Technicznych }\end{array}$ & $\begin{array}{l}\text { Budynek spełniający wymo- } \\
\text { gi Warunków Technicznych }\end{array}$ & $\begin{array}{l}\text { Budynek spełniający wymo- } \\
\text { gi domu pasywnego }\end{array}$ \\
\hline
\end{tabular}




\begin{tabular}{|c|c|c|c|}
\hline & z 2017 roku & $\begin{array}{l}\text { z } 2017 \text { roku w szkielecie } \\
\text { drewnianym }\end{array}$ & \\
\hline $\begin{array}{l}\text { Obliczenia strat (-\%) oraz } \\
\text { zysków (+\%) dla wszystkich } \\
\text { stref termicznych budynku: } \\
\text { od } 1 \text { stycznia do } 31 \text { grudnia: } \\
\text { SOL-AIR + } 55.8 \% \text {, } \\
\text { SOLAR + } 11,6 \% \text {, } \\
\text { WENTYLACJA - } 20,2 \% \text {, } \\
\text { WEWNĘTRZNE +28.7\% }\end{array}$ & $\begin{array}{l}\text { Obliczenia strat (-\%) oraz } \\
\text { zysków (+\%) dla wszystkich } \\
\text { stref termicznych budynku: } \\
\text { od } 1 \text { stycznia do } 31 \text { grudnia: } \\
\text { SOL-AIR +9,5\%, } \\
\text { SOLAR +22,4\%, } \\
\text { WENTYLACJA -55,0\%, } \\
\text { WEWNĘTRZNE }+67,3 \%\end{array}$ & $\begin{array}{l}\text { Obliczenia strat (-\%) oraz } \\
\text { zysków (+\%) dla wszystkich } \\
\text { stref termicznych budynku: } \\
\text { od } 1 \text { stycznia do } 31 \text { grudnia: } \\
\text { SOL-AIR +8,1\%, } \\
\text { SOLAR +22,8\%, } \\
\text { WENTYLACJA - } 71,9 \% \text {, } \\
\text { WEWNĘTRZNE }+68,4 \%\end{array}$ & $\begin{array}{l}\text { Obliczenia strat (-\%) oraz } \\
\text { zysków (+\%) dla wszystkich } \\
\text { stref termicznych budynku: } \\
\text { od } 1 \text { stycznia do } 31 \text { grudnia: } \\
\text { SOL-AIR }+5.1 \% \text {, } \\
\text { SOLAR +45,1\%, } \\
\text { WENTYLACJA -76,5\%, } \\
\text { WEWNĘTRZNE }+47.2 \%\end{array}$ \\
\hline $\begin{array}{l}\text { Zapotrzebowanie energe- } \\
\text { tyczne 294,151 } \\
\text { kWh/m2/rok. }\end{array}$ & $\begin{array}{l}\text { Zapotrzebowanie energe- } \\
\text { tyczne } 57,674 \mathrm{kWh} / \mathrm{m} 2 / \text { rok. }\end{array}$ & $\begin{array}{l}\text { Zapotrzebowanie energe- } \\
\text { tyczne } 63,506 \text { kWh/m2/rok. }\end{array}$ & $\begin{array}{l}\text { Zapotrzebowanie energe- } \\
\text { tyczne } 34,5 \mathrm{k} \mathrm{Wh} / \mathrm{m} 2 / \text { rok. }\end{array}$ \\
\hline
\end{tabular}

W tej samej formule analiz, mających na celu maksymalizację oraz minimalizację badanych parametrów przed oraz po wprowadzonych zmianach, została poddana pozostała grupa budynków. Zostały przebadane obecnie wznoszone domy z osiedli w zabudowie jednorodzinnej na obszarze Pomorza Zachodniego, mianowicie: Osiedle Szeroka, Szczecin (ryc. 9, tab. 10), Osiedle Laurowe, Koszalin (ryc. 10, tab. 11), Osiedle Tęczowe, Stargard (ryc. 11, tab. 12). Obrazuje to przede wszystkim wynik umożliwiający porównanie wprowadzonych zmian jakim został poddany obiekt bazowy uwzględniając zastosowane różne rozwiązania materiałowe oraz przekształcenia w jego formie architektonicznej.

Tab. 10. Analizy budynku z Osiedla Szeroka w Szczecinie. Analiza rocznych zysków i strat energetycznych budynku z zysków biernych z promieniowania słonecznego - analiz dokonano przy użyciu: Autodesk: Ecotect Analysis. Żródło: autor

\begin{tabular}{|l|l|}
\hline Budynek przed zmianami & Budynek po zmianach \\
\hline Obliczenia strat (-\%) oraz zysków (+\%) dla wszystkich stref & Obliczenia strat (-\%) oraz zysków (+\%) dla wszystkich stref \\
termicznych budynku: od 1 stycznia do 31 grudnia: & termicznych budynku: od 1 stycznia do 31 grudnia: \\
SOL-AIR $+4.3 \%$, & SOL-AIR +3,7\%, \\
SOLAR $+19,2 \%$, & SOLAR +28,3\%, \\
WENTYLACJA -70,9\%, & WENTYLACJA -65,7\%, \\
WEWNĘTRZNE +75.5\%. & WEWNĘTRZNE +68,7\%. \\
\hline Zapotrzebowanie energetyczne 49,127 $\mathrm{kWh} / \mathrm{m} 2 /$ rok. & Zapotrzebowanie energetyczne $66.769 \mathrm{kWh} / \mathrm{m} 2 / \mathrm{rok}$. \\
\hline
\end{tabular}

Tab. 11. Analizy budynku z Osiedla Laurowego w Koszalinie. Analiza rocznych zysków i strat energetycznych budynku z zysków biernych z promieniowania słonecznego - analiz dokonano przy użyciu: Autodesk: Ecotect Analysis. Żródło: autor

\begin{tabular}{|l|l|}
\hline Budynek przed zmianami & Budynek po zmianach \\
\hline Obliczenia strat (-\%) oraz zysków (+\%) dla wszystkich stref & Obliczenia strat (-\%) oraz zysków (+\%) dla wszystkich stref \\
termicznych budynku: od 1 stycznia do 31 grudnia: & termicznych budynku: od 1 stycznia do 31 grudnia: \\
SOL-AIR $+5,9 \%$, & SOL-AIR $+5,4 \%$, \\
SOLAR $+21,1 \%$, & SOLAR +26,8\%, \\
WENTYLACJA -70,9\%, & WENTYLACJA -68,6\%, \\
WEWNĘTRZNE +71,6\%. & WEWNĘTRZNE +66,1\%. \\
\hline Zapotrzebowanie energetyczne $88,293 \mathrm{kWh} / \mathrm{m} 2 /$ rok. & Zapotrzebowanie energetyczne $90,750 \mathrm{kWh} / \mathrm{m} 2 / \mathrm{rok}$. \\
\hline
\end{tabular}

Tab. 12. Analizy budynku z Osiedla Tęczowego w Stargardzie. Analiza rocznych zysków i strat energetycznych budynku z zysków biernych z promieniowania słonecznego - analiz dokonano przy użyciu: Autodesk: Ecotect Analysis. Żródło: autor

\begin{tabular}{|l|l|}
\hline Budynek przed zmianami & Budynek po zmianach \\
\hline Obliczenia strat (-\%) oraz zysków (+\%) dla wszystkich stref & Obliczenia strat (-\%) oraz zysków (+\%) dla wszystkich stref \\
termicznych budynku: od 1 stycznia do 31 grudnia: & termicznych budynku: od 1 stycznia do 31 grudnia: \\
SOL-AIR $+5,9 \%$, & SOL-AIR $+5,6 \%$, \\
SOLAR $+19,3 \%$, & SOLAR $+21,8 \%$, \\
WENTYLACJA -70,9\%, & WENTYLACJA -70,1\%, \\
\hline
\end{tabular}


\begin{tabular}{l|l} 
WEWNĘTRZNE $+74.2 \%$ & WEWNĘTRZNE $+71,8 \%$.
\end{tabular}

Zapotrzebowanie energetyczne $67,605 \mathrm{kWh} / \mathrm{m} 2 /$ rok.

Zapotrzebowanie energetyczne $68,684 \mathrm{kWh} / \mathrm{m} 2 /$ rok.

Przedstawione wyniki badań wykonane za pomocą opisanego wcześniej oprogramowania, pokazują efekty biernego pozyskiwania energii słonecznej - zysków i strat energetycznych budynków. Wskazuje się między innymi na zyski z energii słonecznej ze względu na odpowiednie usytuowanie budynku względem stron świata, oraz według projektowanej formy i typu zabudowy (domy wolno stojące, w zabudowie bliźniaczej, w zabudowie szeregowej). Przeprowadzone analizy dotyczą istotnych zagadnień związanych z cyklem życia domu jednorodzinnego. Wskazują one, co jest ważne, na konieczność prowadzenia procesu projektowego, w sposób pozwalający zachować równowagę (balans) pomiędzy projektowaną formą i strukturą budynku a konsumowaną energią w trakcie eksploatacji domu.

\section{WNIOSKI}

Charakterystykę budynku w myśl idei zrównoważonego rozwoju należy oceniać pod względem wpływu na środowisko naturalne, z uwagi na konsumpcję energetyczną oraz wytwarzanie dwutlenku węgla. Przedstawiony materiał zawiera analizę tego pod względem materiałów budowlanych oraz kształtowania formy architektonicznej. Uważa się, że budynki należy planować i projektować pod kątem maksymalnej kompensacji energetycznej oraz materiałowej, tak aby budynek przekroczył swój projektowany okres użytkowania. Wskazuje się, aby wykorzystać w pełni możliwość selekcji proekologicznych materiałów z niskim współczynnikiem GWP, energii wbudowanej, lokalnych, prostych w demontażu, wymianie, itd. Następnie odpowiednie kształtowanie bryły i jej właściwa orientacja względem stron świata zapewni maksymalne pasywne ogrzewanie przyczyniając się do zaspokojenia zapotrzebowania budynku na energię w całym jego cyklu życia. Oba elementy kształtowania budynku znacznie przyczynią się do zmniejszenia emisji dwutlenku węgla. Badania pokazały zaawansowany analityczny charakter aplikacji komputerowych w projektowaniu i roli LCA i BIM w spełnianiu wielu aspektów projektowania. Umożliwiają analizowanie różnych założonych kryteriów w środowisku wirtualnym, przy jednoczesnym wprowadzeniu modyfikacji w celu ulepszenia projektu przed jego zbudowaniem. Jest to główny powód, dla którego analiza budynku (LCA i BIM) jest znacznie bardziej dokładna niż tradycyjne metody. Wdrożenie analizy wydajności budynku niesie wiele korzyści. Oprócz dużych ulepszeń w kontekście zrównoważonego rozwoju, takich jak redukcja emisji $\mathrm{CO}_{2}$, zmniejszenie zużycia energii i wydajności kształtu budynku może przynieść znaczne krótko i długoterminowe oszczędności dla użytkowników i zmaksymalizować potencjalne korzyści względem wpływu na środowisko naturalne. Jednak ta implementacja nie jest pozbawiona ograniczeń. Wdrożenie nowego podejścia do projektowania domów jednorodzinnych wymaga zmian w pracy architekta. Aby to działało, wymaga również modyfikacji prawa i wprowadzenia obowiązku wielokryterialnych analiz BIM i LCA w procesie projektowym.

Należy zatem przyjąć, iż przystępując do projektu warto już na etapie koncepcji architektonicznej wskazać na wielokrotność powtórzeń za pomocą LCA i BIM, kalkulacji wejść i wyjść dotyczących konsumpcji energetycznej oraz redukcji $\mathrm{CO}_{2}$ przy wytworzeniu oraz stosowaniu materiałów budowlanych w strukturze budynku oraz kształtowania formy architektonicznej nastawionej na formę podążającą za energią (ang. form follows energy) (Cody, 2012), formę podążającą za środowiskiem (ang. form follows environment) (Badarnah, 2017), i formę podążającą za energią (ang. form follows energy) (Zacks, 2008), etc. umożliwiając minimalizację wpływu budynku na środowisko. Optymalizacja rozwiązań oraz poszukiwania nowych technik i technologii, zmierzających do minimalizacji wpływu architektury na środowisko, kieruje poszukiwania procesu projektowego ku architekturze adaptującej się do zmieniającego się klimatu na świecie. Kluczowe decyzje projektowe, mające na uwadze wszelkiego rodzaju określenie (minimalizacji) wpływu na środowisko naturalne za pomocą metody Analizy Cyklu Życia (odnoszące się do energii i zastosowanych materiałów), wpływają jednoznacznie na architekturę domu jednorodzinnego.

Należy podkreślić, iż nie można pominąć nakładających się na siebie zależności konstrukcjifunkcji-formy, w dążeniu do harmonijnego kształtowania domu jednorodzinnego, gdzie podsumowaniem ich relacji i integracji jest całościowe spojrzenie na cykl życia projektowanego budynku. 
Tab. 13. Czynniki wpływające na architekturę domów jednorodzinnych na Pomorzu Zachodnim. Źródło: autor

\begin{tabular}{|c|c|c|c|c|}
\hline \multicolumn{5}{|c|}{$\begin{array}{l}\text { WSKAZANIA PROEKOLOGICZNE DLA BADANYCH OBIEKTÓW NA PODSTAWIE LCA i BIM } \\
\text { Z UWZGLEDNIENIEM SPECYFIKI EKOLOGICZNEJ REGIONU }\end{array}$} \\
\hline \multicolumn{5}{|c|}{ Czynniki wpływające na architekturę domów jednorodzinnych na Pomorzu Zachodnim } \\
\hline \multirow[b]{3}{*}{ 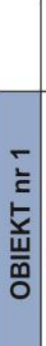 } & & Usytuo & anie & \\
\hline & Materiałowy & $\begin{array}{l}\text { ekspozycja } \\
\text { słoneczna }\end{array}$ & zacienienie & Wiatr i deszcz \\
\hline & $\begin{array}{l}\text { obniżenie wartości GWP w } \\
\text { ścianie zewnętrznej } \\
\text { poprzez zmianę w izolacji } \\
\text { termicznej } \\
\text { ze styropianu EPS } \\
\text { na wetnę mineralną }\end{array}$ & $\begin{array}{l}\text { maksymalizacja powierzchni } \\
\text { nasłonecznionych przez: } \\
\text { - zmiane orientaciji dachu w } \\
\text { kierunku południowym } \\
\text { - zmiane orientacij pokoju } \\
\text { dziennego z kierunku } \\
\text { wschodniego na południowo } \\
\text { wschodni (wzrost rocznego } \\
\text { zysku dla rozwiązań } \\
\text { pasywnych). }\end{array}$ & - & $\begin{array}{l}\text { zastosowanie kształtów } \\
\text { krzywoliniowych nadających } \\
\text { opływowy ksztalt } \\
\text { - kalenica } \\
\text { - narożniki ścian }\end{array}$ \\
\hline & $\begin{array}{l}\text { GWP } 30350,50 \mathrm{kgCO}-\text {-Eq. } \\
\text { PENRTTPERT } \\
381192,07 \mathrm{MJ}\end{array}$ & & & \\
\hline & $\begin{array}{l}\text { lzolacja termiczna: } \\
\text { byt: styropian EPS } \\
\text { jest. wena mineralna } \\
\text { Wyyk: } \\
\text { GWP 20984,31 kgCO2-Eq. } \\
\text { PENRTPERT } \\
271278,02 \mathrm{MJ}\end{array}$ & & & \\
\hline \multirow[t]{3}{*}{ 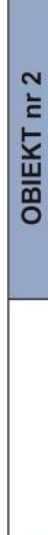 } & $\begin{array}{l}\text { obniżenie wartości GWP } \\
\text { poprzez zmianę w izolacji } \\
\text { termicznej } \\
\text { ze styropianu EPS } \\
\text { na wełnę mineralną }\end{array}$ & $\begin{array}{l}\text { intensyfikacja powierzchni } \\
\text { nasłonecznionych przez: } \\
\text { - zwiększenie powierzchni } \\
\text { dachu } \\
\text { - zmianę wielkości okien } \\
\text { pokoju dziennego (wzrost } \\
\text { rocnnego zysku dla } \\
\text { rozwiązań pasywnych). }\end{array}$ & $\begin{array}{l}\text { - pozbycie się elementów } \\
\text { zacieniających (okapy) } \\
\text { - minimalizacja mostka } \\
\text { termicznego (wiata } \\
\text { garażowa) }\end{array}$ & $\begin{array}{l}\text { usunięcie zbeddnych } \\
\text { elementów (okapy dachu, } \\
\text { wykuszze) } \\
\text { zastosowanie ksztaltów } \\
\text { krzyoliniowych } \\
\text { minimalizujacych obciążenie } \\
\text { wiatrem w: } \\
\text { - kalenica } \\
\text { - narożniki ścian } \\
\text { - wrowandzenie absyd } \\
\text { rozbijajacce obciążenie ściany } \\
\text { frontowej }\end{array}$ \\
\hline & $\begin{array}{l}\text { GWP } 16163,32 \mathrm{kgCO}-\mathrm{Eq} \\
\text { PENRT+PERT 203970,63 MJ }\end{array}$ & & & \\
\hline & $\begin{array}{l}\text { Izolacja termiczna: } \\
\text { byt: styropian EPS } \\
\text { jest: wetna mineralna } \\
\text { Wynik: } \\
\text { GWP } 8708,56 \mathrm{kgCO}-\mathrm{Eq} . \\
\text { PENRT+PERT } \\
116604,28 \mathrm{MJ}\end{array}$ & & & \\
\hline \multirow[t]{2}{*}{ 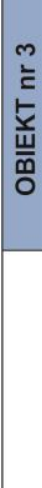 } & $\begin{array}{l}\text { obniżenie wartości GWP w } \\
\text { ścianie zewnêtrznej } \\
\text { poprzez zmianę w izolacji } \\
\text { termicznej } \\
\text { ze styropianu EPS } \\
\text { na welnę mineralną }\end{array}$ & $\begin{array}{l}\text { maksymalizacja powierzchni } \\
\text { nasłonecznionych przez: } \\
\text { - zmianę orientacji połaci } \\
\text { dachowych } \\
\text { w kierunku } \\
\text { wschód-zachód } \\
\text { - zmiane wielkości okien } \\
\text { pokoju dziennego (wzrost } \\
\text { rocznego zysku dla } \\
\text { rozwiązań pasywnych). }\end{array}$ & $\begin{array}{l}\text { zmniejszenie powierzchni } \\
\text { zacienionych przez } \\
\text { obrócenie połaci dachowej }\end{array}$ & $\begin{array}{l}\text { usunięcie zbednych } \\
\text { elementów (okapy dachu) } \\
\text { minimalizujacych obciążenie } \\
\text { wiatrem }\end{array}$ \\
\hline & 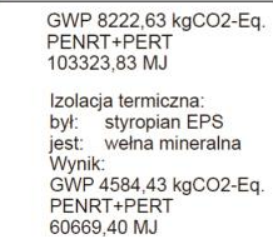 & & & \\
\hline
\end{tabular}

Prawidłowe kształtowanie formy budynku odpowiada za minimalizację negatywnego wpływu na środowisko w całym cyklu życia. Warto dodać, że dobór elementów o wysokim lub niskim współczynniku ekologicznym (absorbcji $\mathrm{CO}_{2}$ przy produkcji, energii wbudowanej, itd.) wpływa równocześnie na estetykę domu. Jednocześnie kształtowanie formy domu powinno uwzględniać przy jej projektowaniu występujący klimat danego obszaru, w którym się znajduje, oraz który może wpływać na formę. Konieczne jest zatem wskazanie czynników mających wpływ na architekturę domów jednorodzinnych na Pomorzu Zachodnim. Czynniki te zostały przedstawione poniżej w tabeli (tab.13). 


\section{BIBLIOGRAPHY}

Badarnah L., Form Follows Environment: Biomimetic Approaches to Building Envelope Design for Environmental Adaptation, DOI: 10.3390/buildings7020040, Buildings 2017, 7(40).

Bayer Ch., Michael G., Gentry R., Surabhi J. 2010. AIA Guide to Building Life Cycle Assessment in Practice, The American Institute of Architects, Washington.

BIP, 2018, http://bip.um.szczecin.pl/files/1F59A64A3FE640B99C6349D70BA76DE5/MPA_Szczecin_BIP_9_listopada18.pdf 2020-10-06

BIP, 2020, http://bip.um.szczecin.pl/chapter_11424.asp 2020-10-06

Cody B., 2017. Form follows Energy. Using natural forces to maximize performance, DOI: 10.1515/9783035614114, Birkhäuser.

Curran M.A. 2012. Life Cycle Assessment Handbook: A Guide for Environmentally Sustainable Products, DOI:10.1002/9781118528372, Wiley-Scrivener.

Czarnecki M., Rytel G. Zagadnienia ekologii i energooszczędności w architekturze - współczesne tendencje w projektowaniu domów jednorodzinnych, ARCHITECTURAE et ARTIBUS (18) 4/2013, Białystok. Pp.11-20.

GUS, http://stat.gov.pl/obszary-tematyczne/przemysl-budownictwo-srodki-trwale/budownictwo/budownictwowyniki-dzialalnosci-w-2016-r-,3,12.html\#archive 2020-10-06

John S., Nebel B., Perez N., Buchanan A., Environmental Impacts of Multi-Storey Buildings Using Different Construction Materials, Research Report 2008-02. Department of Civil and Natural Resources Engineering, University of Canterbury Christchurch, New Zealand 2009.

Kępka M., Kępka M., Kępka B., Audyt turystyczny Województwa Zachodniopomorskiego, MM Marketing i Innowacje, Warszawa 2013.

Koźmiński C., Michalska B., Czarnecka M. 2007. Klimat województwa zachodniopomorskiego, ISBN:978-83751803-7-4, Wydawnictwo Zapol, Szczecin.

Lawrence M. 2015. Reducing the Environmental Impact of Construction by Using Renewable Materials. DOI: 10.7569/JRM.2015.634105, Journal of Renewable Materials, Vol.3, No.3, Scrivener Publishing LLC. Pp.163-174.

Pogoda, http://www.pogoda-zachodniopomorskie.pl 2020-10-06

Program ochrony środowiska województwa zachodniopomorskiego na lata 2016-2020 z perspektywą do 2024. Źródło: http://eregion.wzp.pl/sites/default/files/programochronysrodowiska.pdf (dostęp: 05.06.2020).

Przesmycka N. 2012. Kierunki rozwoju budownictwa jednorodzinnego w Polsce na tle tendencji europejskich, Budownictwo i Architektura Vol. 11(2)2012, Politechnika Lubelska, Lublin. Pp 25-34.

Sarosiek W., Sadowska B. 2009. Ekologiczne aspekty termomodernizacji wybranych budynków mieszkalnych i użyteczności publicznej, Materiały Budowlane nr1. Pp. 76-77.

Zacks S. 2008. Form Follows Performance: The German architect Stefan Behnisch pushes architectural form into new energy-efficient directions. Metropolis Magazine, Bellerophon Publications, Inc. https://www.metropolismag.com/uncategorized/form-follows-performance-2 2020-10-06

\section{AUTHOR'S NOTE}

Piotr Gradziński is scientifically and professionally active, primarily in the field of architecture. He conducts research related to architecture on the principles of sustainable development, taking into account and using the broadly understood Life Cycle Assessment (LCA) and Building Information Modeling (BIM) in the regenerative design process of architecture.

\section{O AUTORZE}

Zajmuje się naukowo i zawodowo przede wszystkim projektowaniem z zakresu architektury. Prowadzi badania związane z architekturą na zasadach zrównoważonego rozwoju z uwzględnieniem i wykorzystaniem szeroko pojętej Analizy i Oceny Cyklu Życia (LCA - Life Cycle Assessment) oraz Modelowania Informacji o Budynku (BIM - Building Information Modeling) w regeneratywnym procesie projektowym architektury.

Contact | Kontakt: Piotr.Gradzinski@zut.edu.pl 